Review

\title{
Mechanical Properties and Deformation Behavior of Bulk Metallic Glasses
}

\author{
Dmitri V. Louzguine-Luzgin ${ }^{1, *}$, Larissa V. Louzguina-Luzgina ${ }^{2}$ and \\ Alexander Yu. Churyumov ${ }^{3}$
}

1 WPI Advanced Institute for Materials Research, Tohoku University, Aoba-Ku, Sendai 980-8577, Japan

2 WPI Advanced Institute for Materials Research, Tohoku University, Aoba-Ku, Sendai 980-8577, Japan; E-Mail: larissalou2@gmail.com

3 National University of Science and Technology "MISiS", Moscow 119049, Russia;

E-Mail: churyumov@misis.ru

* Author to whom correspondence should be addressed; E-Mail: dml@wpi-aimr.tohoku.ac.jp; Tel.: +81-22-217-5957; Fax: +81-22-217-5956.

Received: 2 November 2012; in revised form: 5 December 2012 / Accepted: 10 December 2012 / Published: 20 December 2012

\begin{abstract}
Metallic glasses demonstrate unique properties, including large elastic limit and high strength, which make them attractive for practical applications. Unlike crystalline alloys, metallic glasses, in general, do not exhibit a strain hardening effect, while plastic deformation at room temperature is localized in narrow shear bands. Room-temperature mechanical properties and deformation behavior of bulk metallic glassy samples and the crystal-glassy composites are reviewed in the present paper.
\end{abstract}

Keywords: metallic glasses; deformation; strength; plasticity

\section{Introduction}

Owing to their promising physical and functional properties, bulk metallic glassy alloys, which are also called bulk metallic glasses (BMGs), attract significant attention from materials scientists [1-3]. Zr-based glassy alloys have a high glass forming ability (GFA) compared to other TM-based alloys (TM-transition metals), except for some NM-based (NM-noble metals) alloys, which GFA is significantly enhanced by fluxing. The Zr-LTM (LTM-late transition metal) and Zr-LTM-NM glassy 
alloys may demonstrate a large critical diameter up to $30 \mathrm{~mm}$ and low critical cooling rates below $10 \mathrm{~K} / \mathrm{s}$ [1-3], while Zr-LTM-Ti-Be alloys exhibit even lower critical cooling rates down to $1 \mathrm{~K} / \mathrm{s}$. The purpose of the present work is to review mechanical properties and deformation behavior of BMGs at room and cryogenic temperature.

\section{Mechanical Properties and Deformation of Bulk Metallic Glasses and Composites at Room Temperature}

Owing to the absence of crystalline lattice and dislocations, a unique deformation mechanism is realized in bulk metallic glassy alloys [4,5], which thus, exhibit high strength ( 2 GPa for Cu-, Ti-, Zr-based, $\sim 3 \mathrm{GPa}$ for Ni-based, $\sim 4 \mathrm{GPa}$ for Fe-based, $\sim 5 \mathrm{GPa}$ [6] and even $\sim 6 \mathrm{GPa}$ for Co-based alloys [7]), high hardness, good wear resistance and large elastic deformation. (Fe, Co)-Cr-Mo-C-B-Tm glassy alloys prepared by Amiya and Inoue [8] in a cylindrical form with a diameter of $18 \mathrm{~mm}$ demonstrate an excellent GFA and high strength exceeding $4 \mathrm{GPa}$. $\mathrm{Co}_{43} \mathrm{Fe}_{20} \mathrm{Ta}_{5.5} \mathrm{~B}_{31.5}$ glassy alloy exhibited ultrahigh fracture strength exceeding $5 \mathrm{GPa}$, high Young's modulus of $270 \mathrm{GPa}$, high specific strength and high specific Young's modulus [6]. The strength and specific strength values exceed those reported for any bulk glassy alloys. The highest strength among $\mathrm{Cu}$-based alloys was found for a $\mathrm{Cu}-\mathrm{Zr}$-Ti-Co bulk metallic glass [9].

Mechanical properties of bulk metallic glasses (BMGs) in terms of Yield $\left(\sigma_{\mathrm{y}}\right)$ and Fracture Strength $\left(\sigma_{\mathrm{f}}\right)$, Vickers Hardness as well as the Young's Modulus (E) are given in Tables 1 and 2 (together with the references) while possible correlations are shown in Figure 1. One can admit an excellent correlation between $\sigma_{\mathrm{y}}$ and $\mathrm{HV}\left(R^{2}=0.98\right)$ as expected for isotropic solids like BMGs. Understandably, $\sigma_{\mathrm{f}}$ shows a less good correlation which is connected with different amount of plastic deformation in the case of each alloy. There is also a similar trend with Young's Modulus but the results are more scattered.

Table 1. Composition and mechanical properties of ternary bulk glassy alloys.

\begin{tabular}{ccccccccccc}
\hline & Element & \multicolumn{3}{c}{ Content, at \% } & $\sigma_{\mathbf{y}}$ & $\sigma_{\mathbf{f}}$ & $\mathbf{E}$ & HV & Reference \\
1 & 2 & 3 & 1 & 2 & 3 & & & & & \\
\hline $\mathrm{Al}$ & $\mathrm{La}$ & $\mathrm{Cu}$ & 35 & 55 & 1 & & 880 & 43 & 256 & {$[10]$} \\
$\mathrm{Al}$ & $\mathrm{La}$ & $\mathrm{Cu}$ & 30 & 50 & 20 & & 750 & 32 & 240 & {$[10]$} \\
$\mathrm{Al}$ & $\mathrm{La}$ & $\mathrm{Cu}$ & 25 & 55 & 20 & & 600 & 32 & 213 & {$[10]$} \\
$\mathrm{Al}$ & $\mathrm{La}$ & $\mathrm{Cu}$ & 25 & 50 & 25 & & 535 & 29 & 208 & {$[10]$} \\
$\mathrm{Cu}$ & $\mathrm{Hf}$ & $\mathrm{Al}$ & 50 & 42.5 & 7.5 & & 2370 & 128 & 673 & {$[11]$} \\
$\mathrm{Cu}$ & $\mathrm{Hf}$ & $\mathrm{Al}$ & 52.5 & 40 & 7.5 & & 2345 & 125 & 661 & {$[11]$} \\
$\mathrm{Cu}$ & $\mathrm{Hf}$ & $\mathrm{Al}$ & 52.5 & 40 & 7.5 & & 2344 & 125 & 661 & {$[12]$} \\
$\mathrm{Cu}$ & $\mathrm{Hf}$ & $\mathrm{Al}$ & 50 & 45 & 5 & & 2262 & 121 & 627 & {$[11]$} \\
$\mathrm{Cu}$ & $\mathrm{Hf}$ & $\mathrm{Al}$ & 50 & 45 & 5 & & 2260 & 121 & 627 & {$[12]$} \\
$\mathrm{Cu}$ & $\mathrm{Hf}$ & $\mathrm{Ti}$ & 60 & 25 & 15 & 2010 & 2160 & 124 & & {$[13]$} \\
$\mathrm{Cu}$ & $\mathrm{Hf}$ & $\mathrm{Ti}$ & 60 & 25 & 15 & 2024 & 2088 & 124 & & {$[12]$} \\
$\mathrm{Cu}$ & $\mathrm{Hf}$ & $\mathrm{Ti}$ & 60 & 25 & 15 & 1920 & 2130 & 120 & & {$[14]$} \\
$\mathrm{Cu}$ & $\mathrm{Zr}$ & $\mathrm{Ag}$ & 50 & 45 & 5 & & 1940 & 112 & 599 & {$[15]$} \\
$\mathrm{Cu}$ & $\mathrm{Zr}$ & $\mathrm{Ag}$ & 50 & 45 & 5 & & 1940 & 112 & 599 & {$[15]$} \\
$\mathrm{Cu}$ & $\mathrm{Zr}$ & $\mathrm{Ag}$ & 45 & 47.5 & 7.5 & & 1820 & 108 & 556 & {$[15]$} \\
\hline
\end{tabular}


Table 1. Cont.

\begin{tabular}{|c|c|c|c|c|c|c|c|c|c|c|}
\hline \multicolumn{3}{|c|}{ Element } & \multicolumn{3}{|c|}{ Content, at \% } & \multirow[t]{2}{*}{$\sigma_{\mathrm{y}}$} & \multirow[t]{2}{*}{$\sigma_{\mathrm{f}}$} & \multirow[t]{2}{*}{$\mathbf{E}$} & \multirow[t]{2}{*}{ HV } & \multirow[t]{2}{*}{ Reference } \\
\hline 1 & 2 & 3 & 1 & 2 & 3 & & & & & \\
\hline $\mathrm{Cu}$ & $\mathrm{Zr}$ & $\mathrm{Ag}$ & 45 & 45 & 10 & & 1810 & 108 & 542 & [15] \\
\hline $\mathrm{Cu}$ & $\mathrm{Zr}$ & $\mathrm{Ag}$ & 42.5 & 47.5 & 10 & & 1780 & 106 & 534 & [15] \\
\hline $\mathrm{Cu}$ & $\mathrm{Zr}$ & $\mathrm{Ag}$ & 45 & 50 & 5 & & 1885 & 111 & 585 & [15] \\
\hline $\mathrm{Cu}$ & $\mathrm{Zr}$ & $\mathrm{Al}$ & 47.5 & 47.5 & 5 & 1547 & 2265 & 87 & & [16] \\
\hline $\mathrm{Cu}$ & $\mathrm{Zr}$ & $\mathrm{Al}$ & 55 & 40 & 5 & & 2210 & 115 & 581 & [17] \\
\hline $\mathrm{Cu}$ & $\mathrm{Zr}$ & $\mathrm{Al}$ & 52.5 & 42.5 & 5 & & 2115 & 111 & 573 & {$[17]$} \\
\hline $\mathrm{Cu}$ & $\mathrm{Zr}$ & $\mathrm{Al}$ & 50 & 45 & 5 & & 1885 & 102 & 546 & [17] \\
\hline $\mathrm{Cu}$ & $\mathrm{Zr}$ & $\mathrm{Al}$ & 46 & 46 & 8 & 1894 & 2250 & & 580 & [18] \\
\hline $\mathrm{Cu}$ & $\mathrm{Zr}$ & $\mathrm{Al}$ & 55 & 40 & 5 & & 2210 & 115 & 581 & {$[19,20]$} \\
\hline $\mathrm{Cu}$ & $\mathrm{Zr}$ & $\mathrm{Al}$ & 52.5 & 42.5 & 5 & & 2115 & 111 & 573 & {$[19,20]$} \\
\hline $\mathrm{Cu}$ & $\mathrm{Zr}$ & $\mathrm{Al}$ & 50 & 45 & 5 & & 1885 & 102 & 546 & {$[19,20]$} \\
\hline $\mathrm{Cu}$ & $\mathrm{Zr}$ & $\mathrm{Al}$ & 48 & 48 & 4 & 1199 & 1882 & 103 & & [21] \\
\hline $\mathrm{Cu}$ & $\mathrm{Zr}$ & $\mathrm{Al}$ & 47 & 47 & 6 & 1733 & 2250 & & 580 & [22] \\
\hline $\mathrm{Cu}$ & $\mathrm{Zr}$ & $\mathrm{Ga}$ & 52.5 & 42.5 & 5 & & 1940 & 105 & 552 & [23] \\
\hline $\mathrm{Cu}$ & $\mathrm{Zr}$ & $\mathrm{Ga}$ & 55 & 40 & 5 & & 2025 & 109 & 565 & [23] \\
\hline $\mathrm{Cu}$ & $\mathrm{Zr}$ & $\mathrm{Ga}$ & 52.5 & 40 & 7.5 & & 2130 & 111 & 581 & [23] \\
\hline $\mathrm{Cu}$ & $\mathrm{Zr}$ & $\mathrm{Ga}$ & 57.5 & 40 & 2.5 & & 1910 & 105 & 547 & [23] \\
\hline $\mathrm{Cu}$ & $\mathrm{Zr}$ & $\mathrm{Ti}$ & 60 & 30 & 10 & 1785 & 2150 & 114 & & [24] \\
\hline $\mathrm{Gd}$ & $\mathrm{Al}$ & $\mathrm{Ni}$ & 60 & 30 & 10 & & 1330 & 67 & & [25] \\
\hline $\mathrm{Gd}$ & $\mathrm{Al}$ & $\mathrm{Ni}$ & 55 & 25 & 20 & & 1300 & 65 & & [26] \\
\hline $\mathrm{Gd}$ & $\mathrm{Al}$ & $\mathrm{Ni}$ & 65 & 25 & 10 & & 1300 & 63 & & [26] \\
\hline $\mathrm{Gd}$ & $\mathrm{Co}$ & $\mathrm{Al}$ & 60 & 30 & 10 & & 1186 & 60 & & [25] \\
\hline $\mathrm{Gd}$ & $\mathrm{Co}$ & $\mathrm{Al}$ & 60 & 25 & 15 & & 1250 & 63 & & [25] \\
\hline $\mathrm{Gd}$ & $\mathrm{Co}$ & $\mathrm{Al}$ & 60 & 20 & 20 & & 1240 & 63 & & [25] \\
\hline $\mathrm{Gd}$ & $\mathrm{Ni}$ & $\mathrm{Al}$ & 60 & 25 & 15 & & 1280 & 64 & & [25] \\
\hline $\mathrm{Gd}$ & $\mathrm{Ni}$ & $\mathrm{Al}$ & 60 & 20 & 20 & & 1240 & 63 & & [25] \\
\hline $\mathrm{Gd}$ & $\mathrm{Ni}$ & $\mathrm{Al}$ & 50 & 25 & 25 & & 1320 & 66 & & [26] \\
\hline $\mathrm{La}$ & $\mathrm{Al}$ & $\mathrm{Ni}$ & 45 & 45 & 10 & 1080 & 795 & 52 & 330 & [27] \\
\hline $\mathrm{La}$ & $\mathrm{Al}$ & $\mathrm{Ni}$ & 45 & 35 & 20 & 995 & 720 & 46 & 305 & [27] \\
\hline $\mathrm{La}$ & $\mathrm{Al}$ & $\mathrm{Ni}$ & 50 & 35 & 15 & 950 & 715 & 41 & 290 & [27] \\
\hline $\mathrm{La}$ & $\mathrm{Al}$ & $\mathrm{Ni}$ & 50 & 30 & 20 & 930 & 715 & 41 & 285 & [27] \\
\hline $\mathrm{La}$ & $\mathrm{Al}$ & $\mathrm{NI}$ & 55 & 25 & 20 & 735 & 515 & 34 & 225 & [22] \\
\hline $\mathrm{Mg}$ & $\mathrm{Cu}$ & $\mathrm{Y}$ & 80 & 10 & 10 & 630 & 820 & & 220 & [28] \\
\hline $\mathrm{Mg}$ & $\mathrm{Cu}$ & $\mathrm{Y}$ & 75 & 15 & 10 & & 743 & 50 & & [28] \\
\hline $\mathrm{Mg}$ & $\mathrm{Ni}$ & $\mathrm{Gd}$ & 75 & 15 & 10 & & 929 & & & [29] \\
\hline $\mathrm{Mg}$ & $\mathrm{Ni}$ & $\mathrm{Gd}$ & 70 & 20 & 10 & & 880 & & & [29] \\
\hline $\mathrm{Mg}$ & $\mathrm{Ni}$ & $\mathrm{Gd}$ & 70 & 15 & 15 & & 965 & & & [29] \\
\hline $\mathrm{Mg}$ & $\mathrm{Ni}$ & $\mathrm{Gd}$ & 65 & 25 & 10 & & 884 & & & [29] \\
\hline $\mathrm{Mg}$ & $\mathrm{Ni}$ & $\mathrm{Gd}$ & 65 & 20 & 15 & & 909 & & & [29] \\
\hline $\mathrm{Mg}$ & $\mathrm{Ni}$ & $\mathrm{Gd}$ & 60 & 25 & 15 & & 869 & & & [29] \\
\hline $\mathrm{Mg}$ & $\mathrm{Ni}$ & $\mathrm{Y}$ & 82.5 & 12.5 & 5 & & 610 & 44 & 212 & [30] \\
\hline $\mathrm{Mg}$ & $\mathrm{Ni}$ & $\mathrm{Y}$ & 80 & 15 & 5 & & 830 & 46 & 224 & [30] \\
\hline $\mathrm{Mg}$ & $\mathrm{Ni}$ & $\mathrm{Y}$ & 85 & 10 & 5 & & 640 & 40 & 193 & [30] \\
\hline
\end{tabular}


Table 1. Cont.

\begin{tabular}{|c|c|c|c|c|c|c|c|c|c|c|}
\hline \multicolumn{3}{|c|}{ Element } & \multicolumn{3}{|c|}{ Content, at \% } & \multirow[t]{2}{*}{$\sigma_{\mathrm{y}}$} & \multirow[t]{2}{*}{$\sigma_{\mathrm{f}}$} & \multirow[t]{2}{*}{$\mathbf{E}$} & \multirow[t]{2}{*}{ HV } & \multirow[t]{2}{*}{ Reference } \\
\hline 1 & 2 & 3 & 1 & 2 & 3 & & & & & \\
\hline $\mathrm{Zr}$ & $\mathrm{Al}$ & $\mathrm{Ni}$ & 70 & 10 & 20 & 1411 & 1335 & 61 & 432 & {$[31]$} \\
\hline $\mathrm{Zr}$ & $\mathrm{Al}$ & $\mathrm{Ni}$ & 65 & 10 & 25 & 1581 & 1520 & 64.5 & 484 & [31] \\
\hline $\mathrm{Zr}$ & $\mathrm{Al}$ & $\mathrm{Ni}$ & 65 & 15 & 20 & 1614 & 1640 & 70.5 & 494 & {$[31]$} \\
\hline $\mathrm{Zr}$ & $\mathrm{Al}$ & $\mathrm{Ni}$ & 60 & 15 & 25 & 1640 & 1715 & 72.6 & 502 & [31] \\
\hline $\mathrm{Zr}$ & $\mathrm{Al}$ & $\mathrm{Ni}$ & 60 & 20 & 20 & 1795 & 1720 & 78.2 & 549 & [31] \\
\hline $\mathrm{Zr}$ & Co & $\mathrm{Al}$ & 55 & 30 & 15 & & 1790 & 98 & 543 & {$[32]$} \\
\hline $\mathrm{Zr}$ & $\mathrm{Co}$ & $\mathrm{Al}$ & 55 & 25 & 20 & & 1750 & 96 & 530 & {$[32]$} \\
\hline $\mathrm{Zr}$ & Co & $\mathrm{Al}$ & 55 & 25 & 20 & & 1900 & 114 & & [33] \\
\hline $\mathrm{Zr}$ & $\mathrm{Cu}$ & $\mathrm{Al}$ & 50 & 40 & 10 & & 1821 & 89 & & [34] \\
\hline $\mathrm{Zr}$ & $\mathrm{Cu}$ & $\mathrm{Al}$ & 50 & 40 & 10 & & 1860 & 88 & 496 & {$[35]$} \\
\hline $\mathrm{Zr}$ & $\mathrm{Cu}$ & $\mathrm{Al}$ & 52.5 & 37.5 & 10 & & 1840 & 86 & 485 & {$[32,36]$} \\
\hline $\mathrm{Zr}$ & $\mathrm{Cu}$ & $\mathrm{Al}$ & 50 & 37.5 & 12.5 & & 1960 & 93 & 511 & {$[32,36]$} \\
\hline $\mathrm{Zr}$ & $\mathrm{Cu}$ & $\mathrm{Al}$ & 50 & 42.5 & 7.5 & & 1820 & 86 & 475 & {$[32,36]$} \\
\hline $\mathrm{Zr}$ & $\mathrm{Cu}$ & $\mathrm{Al}$ & 55 & 35 & 10 & & 1810 & 83 & 470 & {$[36]$} \\
\hline $\mathrm{Zr}$ & $\mathrm{Cu}$ & $\mathrm{Al}$ & 60 & 30 & 10 & & 1720 & 80 & 446 & {$[36]$} \\
\hline $\mathrm{Zr}$ & $\mathrm{Cu}$ & $\mathrm{Al}$ & 47.5 & 42.5 & 10 & & 1920 & 90 & 508 & [36] \\
\hline $\mathrm{Zr}$ & $\mathrm{Ni}$ & $\mathrm{Al}$ & 60 & 25 & 15 & & 1760 & 88 & 495 & [31] \\
\hline $\mathrm{Zr}$ & $\mathrm{Ni}$ & $\mathrm{Al}$ & 55 & 25 & 20 & & 1780 & 89 & 502 & {$[31,37]$} \\
\hline $\mathrm{Zr}$ & $\mathrm{Ni}$ & $\mathrm{Al}$ & 55 & 30 & 15 & & 1820 & 99 & 514 & {$[31,37]$} \\
\hline $\mathrm{Zr}$ & $\mathrm{Ni}$ & $\mathrm{Al}$ & 60 & 20 & 20 & 1793 & 1720 & 78.2 & 549 & {$[38]$} \\
\hline $\mathrm{Zr}$ & $\mathrm{Ni}$ & $\mathrm{Al}$ & 70 & 20 & 10 & 1411 & 1335 & 61 & 432 & {$[31,39]$} \\
\hline $\mathrm{Zr}$ & $\mathrm{Ni}$ & $\mathrm{Al}$ & 65 & 25 & 10 & 1520 & 1581 & 64.5 & 484 & {$[31,39]$} \\
\hline $\mathrm{Zr}$ & $\mathrm{Ni}$ & $\mathrm{Al}$ & 65 & 20 & 15 & 1614 & 1640 & & 494 & {$[31,39]$} \\
\hline $\mathrm{Zr}$ & $\mathrm{Ni}$ & $\mathrm{Al}$ & 60 & 25 & 15 & 1640 & 1715 & & 502 & {$[31,39]$} \\
\hline $\mathrm{Zr}$ & $\mathrm{Ni}$ & $\mathrm{Ti}$ & 40 & 37 & 23 & & 1630 & & 524 & {$[40]$} \\
\hline
\end{tabular}

Table 2. Composition and mechanical properties of quaternary bulk glassy alloys.

\begin{tabular}{|c|c|c|c|c|c|c|c|c|c|c|c|c|}
\hline \multicolumn{4}{|c|}{ Element } & \multicolumn{4}{|c|}{ Content, at \% } & \multirow[t]{2}{*}{$\sigma_{\mathrm{y}}$} & \multirow[t]{2}{*}{$\sigma_{\mathrm{f}}$} & \multirow[t]{2}{*}{$\mathbf{E}$} & \multirow[t]{2}{*}{ HV } & \multirow[t]{2}{*}{ Reference } \\
\hline 1 & 2 & 3 & 4 & 1 & 2 & 3 & 4 & & & & & \\
\hline $\mathrm{Ce}$ & $\mathrm{Al}$ & $\mathrm{Cu}$ & $\mathrm{Co}$ & 68 & 10 & 20 & 2 & & 1180 & 31.34 & & {$[41]$} \\
\hline $\mathrm{Ce}$ & $\mathrm{Al}$ & $\mathrm{Cu}$ & $\mathrm{Fe}$ & 68 & 10 & 20 & 2 & & 1232 & 32.7 & & [41] \\
\hline $\mathrm{Ce}$ & $\mathrm{Al}$ & $\mathrm{Cu}$ & $\mathrm{Nb}$ & 68 & 10 & 20 & 2 & & 1165 & 30.95 & & [41] \\
\hline $\mathrm{Ce}$ & $\mathrm{Al}$ & $\mathrm{Cu}$ & $\mathrm{Ni}$ & 68 & 10 & 20 & 2 & & 1198 & 31.93 & & [41] \\
\hline Co & $\mathrm{Fe}$ & $\mathrm{Ta}$ & B & 38 & 25 & 5.5 & 31.5 & & 5185 & 268 & & {$[42]$} \\
\hline $\mathrm{Cu}$ & $\mathrm{Hf}$ & $\mathrm{Ti}$ & $\mathrm{Ta}$ & 56.4 & 23.5 & 14.1 & 6 & 2125 & 2100 & 104 & & {$[43]$} \\
\hline $\mathrm{Cu}$ & $\mathrm{Zr}$ & $\mathrm{Ag}$ & $\mathrm{Al}$ & 45 & 45 & 7 & 3 & & 1836 & 110 & 540 & [44] \\
\hline $\mathrm{Cu}$ & $\mathrm{Zr}$ & $\mathrm{Ag}$ & $\mathrm{Al}$ & 45 & 45 & 5 & 5 & & 1890 & 112 & 556 & {$[44]$} \\
\hline $\mathrm{Cu}$ & $\mathrm{Zr}$ & $\mathrm{Ag}$ & $\mathrm{Al}$ & 45 & 45 & 3 & 7 & & 1912 & 112 & 561 & [44] \\
\hline $\mathrm{Cu}$ & $\mathrm{Zr}$ & Hf & $\mathrm{Ag}$ & 45 & 25 & 20 & 10 & & 2000 & 122 & 579 & [41] \\
\hline $\mathrm{Cu}$ & $\mathrm{Zr}$ & $\mathrm{Ti}$ & $\mathrm{Be}$ & 55.5 & 27.75 & 9.25 & 7.5 & & 2450 & 146 & 710 & [45] \\
\hline $\mathrm{Cu}$ & $\mathrm{Zr}$ & $\mathrm{Ti}$ & $\mathrm{Y}$ & 58.8 & 29.4 & 9.8 & 2 & 1780 & 2050 & 115 & & [46] \\
\hline $\mathrm{Fe}$ & $\mathrm{Si}$ & B & $\mathrm{Nb}$ & 72 & 9.6 & 14.4 & 4 & & 4200 & 200 & & [47] \\
\hline $\mathrm{La}$ & $\mathrm{Al}$ & $\mathrm{Cu}$ & $\mathrm{Ag}$ & 62.5 & 12.5 & 20 & 5 & & 640 & 36 & 201 & [48] \\
\hline
\end{tabular}


Table 2. Cont.

\begin{tabular}{|c|c|c|c|c|c|c|c|c|c|c|c|c|}
\hline \multicolumn{4}{|c|}{ Element } & \multicolumn{4}{|c|}{ Content, at \% } & \multirow[t]{2}{*}{$\sigma_{\mathrm{y}}$} & \multirow[t]{2}{*}{$\sigma_{\mathrm{f}}$} & \multirow[t]{2}{*}{$\mathbf{E}$} & \multirow[t]{2}{*}{ HV } & \multirow[t]{2}{*}{ Reference } \\
\hline 1 & 2 & 3 & 4 & 1 & 2 & 3 & 4 & & & & & \\
\hline $\mathrm{La}$ & $\mathrm{Al}$ & $\mathrm{Cu}$ & $\mathrm{Ag}$ & 55 & 15 & 20 & 10 & & 758 & 42 & 208 & {$[48]$} \\
\hline $\mathrm{Mg}$ & $\mathrm{Cu}$ & $\mathrm{Ni}$ & $\mathrm{Gd}$ & 65 & 5 & 20 & 10 & & 874 & 54 & & [49] \\
\hline $\mathrm{Mg}$ & $\mathrm{Y}$ & $\mathrm{Zn}$ & $\mathrm{Cu}$ & 65 & 10 & 5 & 20 & & 860 & 74 & & {$[50]$} \\
\hline $\mathrm{Ni}$ & $\mathrm{Nb}$ & $\mathrm{Ti}$ & $\mathrm{Zr}$ & 60 & 15 & 10 & 15 & & 2770 & 156 & & {$[51]$} \\
\hline $\mathrm{Ni}$ & $\mathrm{Si}$ & $\mathrm{B}$ & $\mathrm{Nb}$ & 72 & 7.68 & 16.32 & 4 & & 2510 & 77 & 870 & {$[52]$} \\
\hline $\mathrm{Ni}$ & $\mathrm{Si}$ & B & $\mathrm{Ta}$ & 72 & 7.68 & 16.32 & 4 & & 2730 & 75 & 920 & {$[52]$} \\
\hline $\mathrm{Ni}$ & $\mathrm{Ta}$ & $\mathrm{Ti}$ & $\mathrm{Zr}$ & 60 & 15 & 15 & 10 & & 3180 & 67 & & [53] \\
\hline $\mathrm{Pd}$ & $\mathrm{Cu}$ & $\mathrm{Ni}$ & $\mathrm{P}$ & 40 & 30 & 10 & 20 & & 1640 & & 515 & {$[54]$} \\
\hline $\mathrm{Pd}$ & $\mathrm{Cu}$ & $\mathrm{Si}$ & $\mathrm{P}$ & 79 & 6 & 10 & 5 & 1475 & 1575 & 82 & & {$[55]$} \\
\hline $\mathrm{Pd}$ & $\mathrm{Pt}$ & $\mathrm{Cu}$ & $\mathrm{P}$ & 35 & 15 & 30 & 20 & 1410 & & & 470 & [56] \\
\hline $\mathrm{Pt}$ & $\mathrm{Cu}$ & $\mathrm{Ni}$ & $\mathrm{P}$ & 57.5 & 14.7 & 5.3 & 22.5 & 1400 & 1470 & & & [57] \\
\hline $\mathrm{Ti}$ & $\mathrm{Ni}$ & $\mathrm{Cu}$ & $\mathrm{Sn}$ & 50 & 20 & 25 & 5 & & 2050 & 102 & 650 & [58] \\
\hline $\mathrm{Ti}$ & $\mathrm{Ni}$ & $\mathrm{Cu}$ & $\mathrm{Sn}$ & 50 & 20 & 23 & 7 & & 2200 & 105 & 670 & [58] \\
\hline $\mathrm{Ti}$ & $\mathrm{Ni}$ & $\mathrm{Cu}$ & $\mathrm{Sn}$ & 50 & 22 & 25 & 3 & & 2050 & 98 & 640 & [58] \\
\hline $\mathrm{Zr}$ & $\mathrm{Al}$ & $\mathrm{Co}$ & $\mathrm{Cu}$ & 55 & 20 & 20 & 5 & 2000 & 1960 & 92 & & [59] \\
\hline $\mathrm{Zr}$ & $\mathrm{Al}$ & $\mathrm{Ni}$ & $\mathrm{Pd}$ & 65 & 7.5 & 10 & 17.5 & 1340 & 1510 & & & {$[60]$} \\
\hline $\mathrm{Zr}$ & $\mathrm{Cu}$ & $\mathrm{Ni}$ & $\mathrm{Al}$ & 52 & 32 & 4 & 12 & & 1780 & 88 & 501 & [61] \\
\hline $\mathrm{Zr}$ & $\mathrm{Cu}$ & $\mathrm{Ni}$ & $\mathrm{Al}$ & 52 & 30 & 6 & 12 & & 1820 & 93 & 506 & [61] \\
\hline $\mathrm{Zr}$ & $\mathrm{Cu}$ & $\mathrm{Ni}$ & $\mathrm{Al}$ & 50 & 26 & 12 & 12 & & 1878 & 88 & 498 & [61] \\
\hline $\mathrm{Zr}$ & $\mathrm{Cu}$ & $\mathrm{Ni}$ & $\mathrm{Al}$ & 50 & 34 & 4 & 12 & & 1905 & 91 & 517 & [61] \\
\hline $\mathrm{Zr}$ & $\mathrm{Cu}$ & $\mathrm{Ni}$ & $\mathrm{Al}$ & 48 & 32 & 8 & 12 & & 1894 & 94 & 513 & [61] \\
\hline $\mathrm{Zr}$ & $\mathrm{Cu}$ & $\mathrm{Ni}$ & $\mathrm{Al}$ & 50 & 32 & 6 & 12 & & 1875 & 92 & 521 & [61] \\
\hline $\mathrm{Zr}$ & $\mathrm{Cu}$ & $\mathrm{Ni}$ & $\mathrm{Al}$ & 52 & 28 & 8 & 12 & & 1798 & 94 & 512 & [61] \\
\hline $\mathrm{Zr}$ & $\mathrm{Cu}$ & $\mathrm{Ni}$ & $\mathrm{Al}$ & 50 & 30 & 8 & 12 & & 1820 & 92 & 526 & [61] \\
\hline $\mathrm{Zr}$ & $\mathrm{Cu}$ & $\mathrm{Ni}$ & $\mathrm{Al}$ & 46 & 34 & 8 & 12 & & 1777 & 111 & 562 & [61] \\
\hline $\mathrm{Zr}$ & $\mathrm{Cu}$ & $\mathrm{Ni}$ & $\mathrm{Al}$ & 48 & 28 & 12 & 12 & & 1906 & 102 & 530 & [61] \\
\hline $\mathrm{Zr}$ & $\mathrm{Cu}$ & $\mathrm{Ni}$ & $\mathrm{Al}$ & 48 & 34 & 6 & 12 & & 1899 & 94 & 529 & [61] \\
\hline $\mathrm{Zr}$ & $\mathrm{Cu}$ & $\mathrm{Ni}$ & $\mathrm{Al}$ & 50 & 28 & 10 & 12 & & 1993 & 92 & 517 & [61] \\
\hline $\mathrm{Zr}$ & $\mathrm{Cu}$ & $\mathrm{Ni}$ & $\mathrm{Al}$ & 48 & 30 & 10 & 12 & & 1378 & 94 & 520 & [61] \\
\hline $\mathrm{Zr}$ & $\mathrm{Cu}$ & $\mathrm{Ni}$ & $\mathrm{Al}$ & 48 & 30 & 10 & 12 & & 1980 & 92 & 528 & [61] \\
\hline $\mathrm{Zr}$ & $\mathrm{Cu}$ & $\mathrm{Ni}$ & $\mathrm{Al}$ & 52 & 26 & 10 & 12 & & 1960 & 89 & 509 & [61] \\
\hline $\mathrm{Zr}$ & $\mathrm{Cu}$ & $\mathrm{Ni}$ & $\mathrm{Al}$ & 46 & 30 & 12 & 12 & & 1399 & 106 & 552 & [61] \\
\hline $\mathrm{Zr}$ & $\mathrm{Cu}$ & $\mathrm{Fe}$ & $\mathrm{Al}$ & 60 & 25 & 5 & 10 & 1643 & & 92 & & [62] \\
\hline $\mathrm{Zr}$ & $\mathrm{Cu}$ & $\mathrm{Fe}$ & $\mathrm{Al}$ & 60 & 20 & 10 & 10 & 1708 & & 104 & & [62] \\
\hline $\mathrm{Zr}$ & $\mathrm{Fe}$ & $\mathrm{Al}$ & $\mathrm{Cu}$ & 60 & 10 & 7.5 & 22.5 & 1718 & & 100 & & [62] \\
\hline
\end{tabular}


Figure 1. Correlation between mechanical properties of bulk metallic glasses. Here $S_{\mathrm{y}}$ and $\mathrm{S}_{\mathrm{f}}$ denote Yield and Fracture Strength, respectively. Triangles denote ternary while diamonds quaternary alloys.
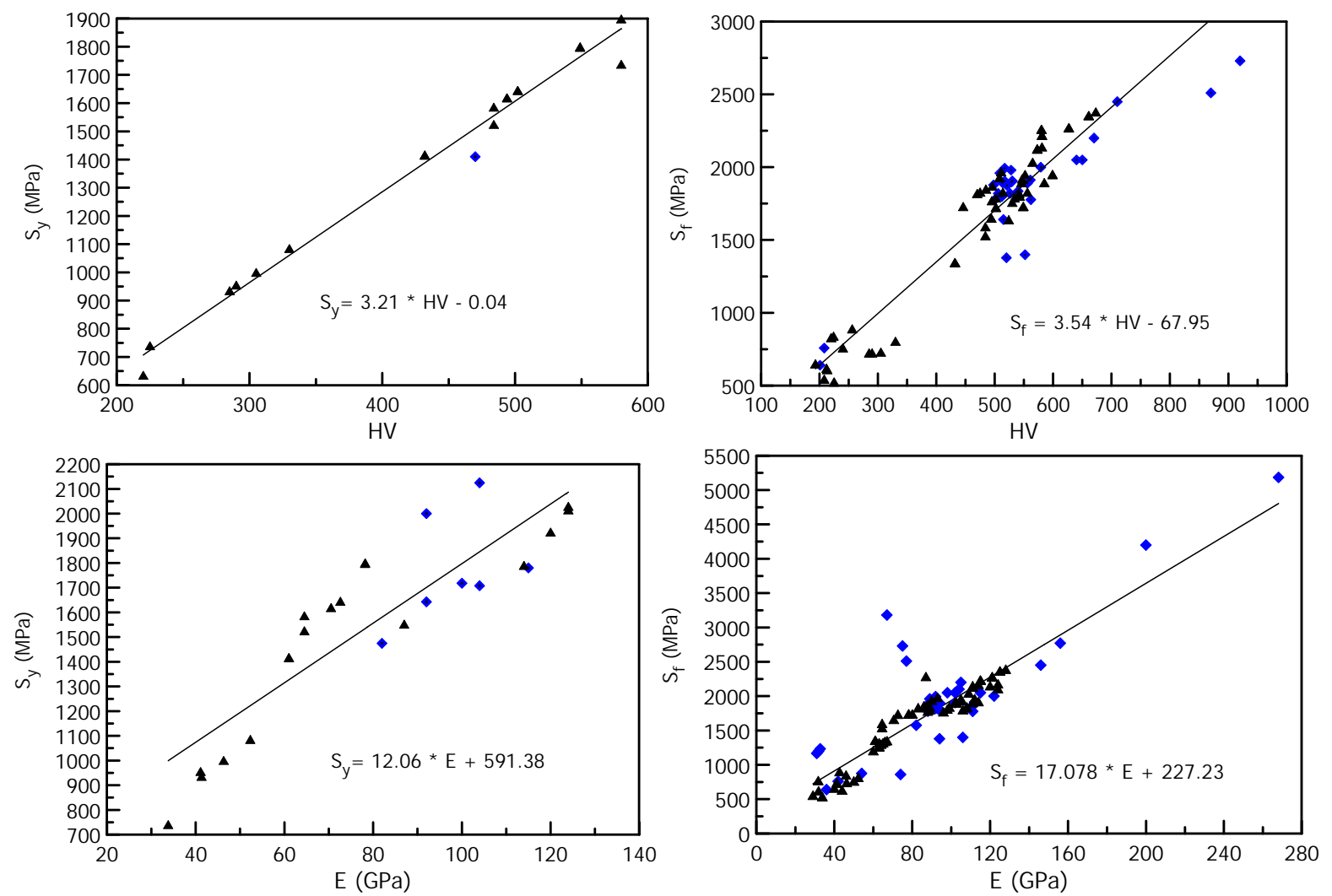

Unless phase separated, bulk metallic glasses are isotropic solids, and thus, their mechanical properties are much less dependent of the processing history than those of crystalline alloys which microstructure can be modified in a wide range resulting in different mechanical properties. Structural relaxation on annealing modifies their plasticity/toughness but very slightly Yield Strength or hardness values.

Although, a vast majority of bulk metallic glasses break shortly after yielding at ambient temperature, the deformation behavior of bulk metallic glassy alloys is under intense investigations at present owing to their high strength. At relatively low homologous temperatures the inhomogeneous plastic flow of glassy alloys occurs by propagation of shear bands [63] which are 10-20 nm thick and make steps on the surface up to several micrometers in height [64]. A strongly localized shear deformation at room temperature $[65,66]$ limits practical application of such materials since a shear event may trigger a crack nucleation and rapid fracture. However, as illustrated in Figure 2, considerable apparent ductility was observed in several specific bulk metallic glassy alloys $[67,68]$.

$\mathrm{Pd}_{40} \mathrm{Ni}_{40} \mathrm{Si}_{x} \mathrm{P}_{20-x}$ [69,70], $\mathrm{Zr}-\mathrm{Cu}-\mathrm{Fe}-\mathrm{Al}$ [71] and $\mathrm{Zr}_{65} \mathrm{Al}_{7.5} \mathrm{Ni}_{10} \mathrm{Pd}_{17.5}$ [72] alloys exhibit significant room-temperature ductility of several percent and high fracture strength in the glassy state. Especially, ductility of the $\mathrm{Pd}_{40} \mathrm{Ni}_{40} \mathrm{Si}_{4} \mathrm{P}_{16}$ BMG is drastically improved by application of $\mathrm{B}_{2} \mathrm{O}_{3}$ fluxing technique [70]. Similar results were obtained for $\mathrm{Pt}_{57.5} \mathrm{Cu}_{14.7} \mathrm{Ni}_{5.3} \mathrm{P}_{22.5}$ [73] alloy though no structural characterization was provided. Large plasticity was explained owing to high elastic moduli ratio G/B or Poisson's ratio [74]. Further investigations on this subject were taken recently and embrittlement of 
Mg- and La-based alloys is caused by the inclusions of oxides (oxygen is insoluble in solid $\mathrm{Mg}$ and La, while it dissolves very well in $\mathrm{Zr}$ and $\mathrm{Ti}$ ) acting as stress concentrators [75]. Zr-Cu-Fe-Al bulk glassy alloy exhibits phase separation on heating prior to crystallization [76], which also may be responsible for its higher room-temperature ductility compared to $\mathrm{Zr}-\mathrm{Cu}-\mathrm{Al}$ alloys.

A stress-strain curve in the plastic deformation range, which is typical for ductile bulk metallic glassy alloys, [77,78] is shown in Figure 2. One can see general absence of strain hardening. The average stress drop magnitude increases with strain, reaching a sort of a critical value at break. The amount of stress drop at each serration event increases with the degree of deformation.

Figure 2. A part of the true stress-strain diagram of $\mathrm{Zr}_{60} \mathrm{Cu}_{25} \mathrm{Fe}_{5} \mathrm{Al}_{10}$ glassy alloy tested at room temperature.

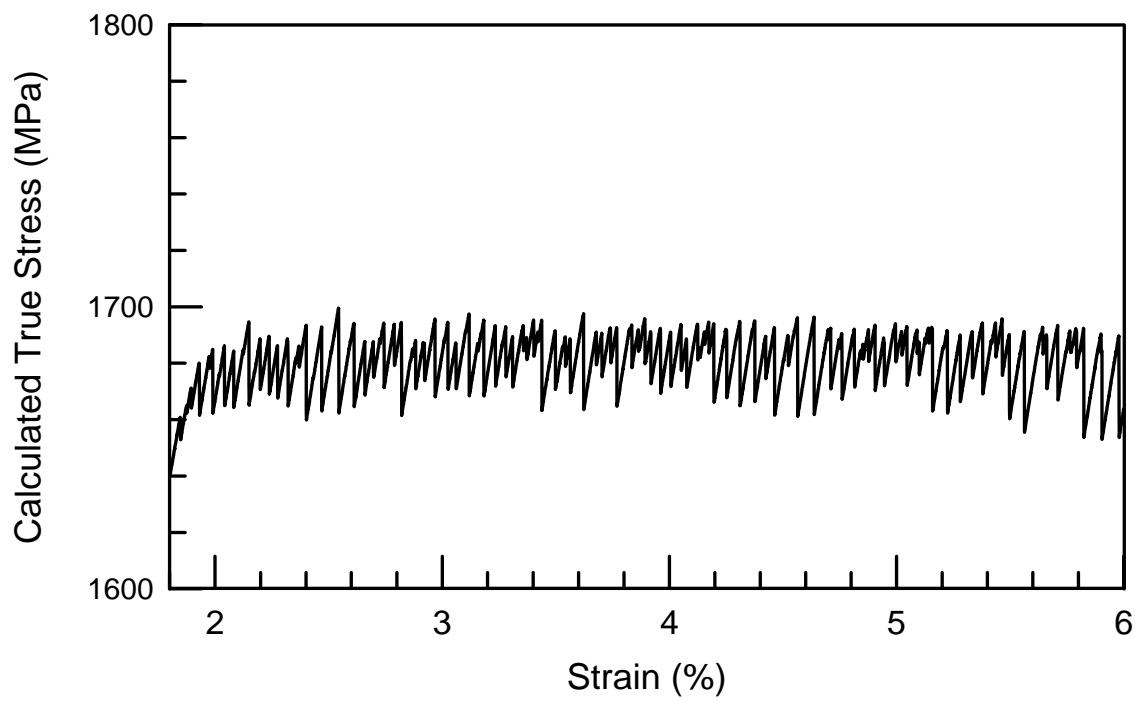

It was shown that fracture of bulk metallic glasses is very sensitive to macroscopic defects (likely pores and surface imperfections) which explains large scattering in the values of the percentage deformation changing from sample to sample [79]. One should also remember that the engineering plasticity of bulk metallic glasses depends upon their geometry and aspect ratio [80,81]. Different specimen geometries influence the shear-band formation and deformation processes, resulting in variations of mechanical properties.

In situ monitoring of the deformation behavior of bulk metallic glasses was performed using an infrared camera. Although temporal resolution of the existing cameras is not high enough, some weak rise of temperature was observed as a result of shear band operation [82].

Fatigue properties of BMG alloys have been also studied and fatigue-endurance limits of some Zr-based alloys are comparable with those of high-strength crystalline alloys [83].

As a localized shear deformation is a dominant plastic-deformation mode at room temperature (Figure 3), tensile ductility is not observed in bulk metallic glassy samples except in a few special cases at high strain rates [84]. Nevertheless, some BMGs demonstrate the formation of multiple shear bands (Figure 3a) while others deform through a major single shear band leading to crack formation (Figure 3b). 
Figure 3. Two regimes of deformation observed in metallic glasses: (a) relatively homogeneous deformation with many shear bands in the $\mathrm{Zr}_{62.5} \mathrm{Cu}_{22.5} \mathrm{Fe}_{5} \mathrm{Al}_{10}$ BMG and (b) stick-slip behavior in a single major shear band in the $\mathrm{Zr}_{67.5} \mathrm{Cu}_{17.5} \mathrm{Fe}_{5} \mathrm{Al}_{10} \mathrm{BMG}_{\text {(SEM). }}$ Reprinted from [71] with permission of Elsevier.

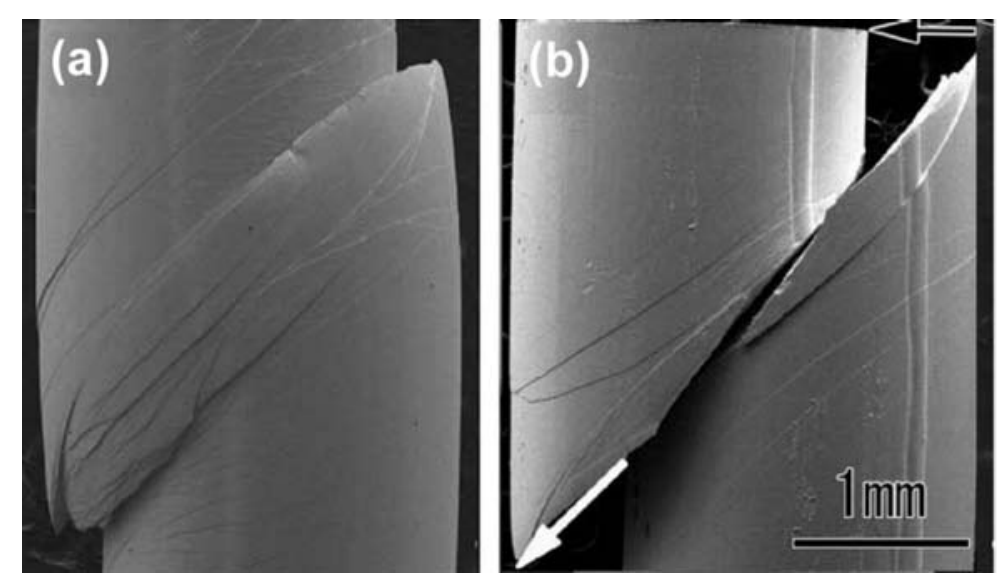

In order to enhance the ductility of metallic glasses, the formation of heterogeneous microstructures in a composite-like manner has been found recently essential and employed in a variety of procedures combining a glassy matrix with second phase crystalline particles $[85,86]$; the deformation-induced nanocrystallization $[87,88]$ is one of the possible ways illustrating this approach. One of the ways is to impede the propagation of shear bands through the sample by interaction with the phases (or microscopic pores) embedded into a glassy matrix. This enables multiplication, branching and termination of the shear bands similar to the composites where cracks are either blocked by reinforcements or blunted in ductile phases or matrix.

The blockage of the crack-tip area by nanoparticles stabilizing plastic deformation was observed in $\mathrm{Cu}_{50} \mathrm{Zr}_{50}$ as well as in the $\mathrm{Zr}_{65} \mathrm{Al}_{7.5} \mathrm{Ni}_{10} \mathrm{Pd}_{17.5}$ glassy alloys [89]. Moreover, the compressive room-temperature stress-strain curves of the $\mathrm{Zr}_{65} \mathrm{Al}_{7.5} \mathrm{Ni}_{10} \mathrm{Cu}_{17.5}$ and $\mathrm{Zr}_{65} \mathrm{Al}_{7.5} \mathrm{Ni}_{10} \mathrm{Pd}_{17.5}$ bulk metallic glassy alloys revealed significantly different plasticity of these alloys, though both of the alloys possess a glassy structure [90].

An alloy, which crystallizes by the nucleation and growth mechanism, is supposed to be less prone to nanocrystalsization during deformation while the alloy having pre-existing nuclei is predisposed to show such a behavior [91]. For example, the precipitation of the nanoscale $\alpha$-Al particles at room temperature was observed in marginal Al-TM-RE glass-formers (like $\mathrm{Al}_{90} \mathrm{Fe}_{5} \mathrm{Gd}_{5}$ or $\mathrm{Al}_{90} \mathrm{Fe}_{5} \mathrm{Ce}_{5}$ ) within the shear bands on deformation [92,93], while a very limited fraction or complete absence of nanocrystals (depending on RE metal) was observed after significant plastic deformation in the $\mathrm{Al}_{85} \mathrm{RE}_{8} \mathrm{Ni}_{5} \mathrm{Co}_{2}$ amorphous and glassy samples [94] ( $\sim 30 \%$ reduction in thickness) which undergo a clear nucleation and growth behavior.

The nanocrystallization within the shear bands was also observed in the $\mathrm{Cu}_{47.5} \mathrm{Zr}_{47.5} \mathrm{Al}_{5}$ glassy alloy, which was reported to be strain-hardenable [87,95]. The effect of strain rate on the flow stress [96] and ductility was studied [97,98] and the results showed that the higher strain rate used facilitates plasticity.

In general, bulk metallic glasses exhibit so-called vein patterns on the fracture surface. On the other hand, fracture surface of a Zr-based bulk glassy alloy [99], exhibited alternating areas of vein and flat 
fracture surfaces (Figure 4). A fracture surface topography showing initial cleavage-like behavior starting from the lateral surface of the rod sample has long been known [100]. However, in the present case the several cleavage-like and vein patterns alternate in the body of the sample in the direction normal to shear deformation. Thus, cleavage-like areas may be considered as the areas of significant shear deformation. The vein fracture patterns, which are specific to metallic glasses, may signify local melting of the material at the surface upon fracture [101,102], and thus, existence of considerable temperature gradients in the deforming sample. Novel fracture behavior of Pd-based bulk metallic glasses with wavy features was also reported recently by Chen [103].

Figure 4. Fracture surface of the $\mathrm{Zr}_{60} \mathrm{Cu}_{16} \mathrm{Ni}_{14} \mathrm{Al}_{10}$ bulk glassy alloy tested at room temperature (SEM).

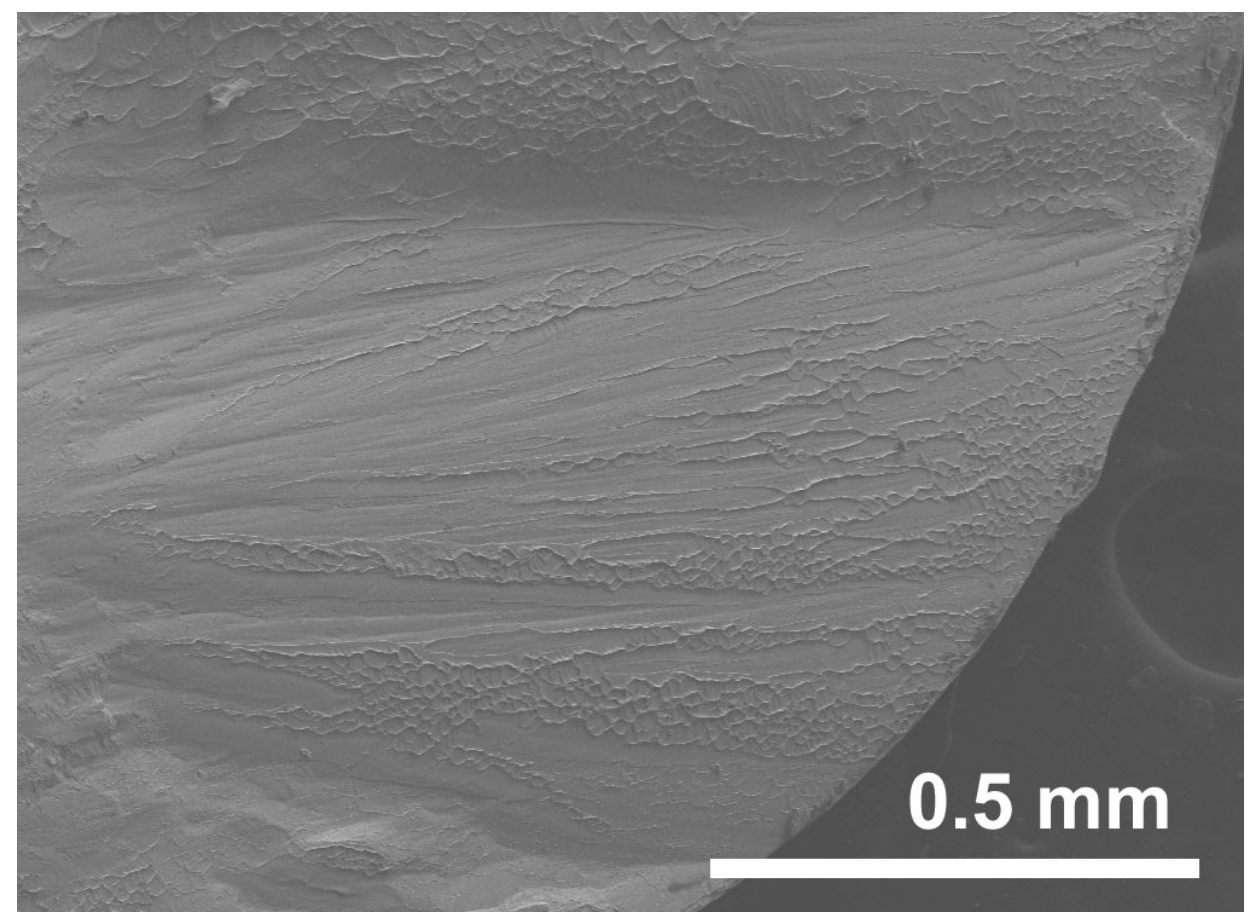

The mechanisms of ductilization of bulk metallic glassy alloys by crystalline and quasicrystalline inclusions have been studied before. Most commonly, they are associated with blocking and branching of the propagating localized shear bands by the structural inhomogeneities like inclusions [86]. Bulk glassy-crystal composites with considerable tensile ductility were produced in Zr-based system alloys with large Be content [104,105]. An interesting result was obtained recently for a $\mathrm{Ni}-\mathrm{Cu}-\mathrm{Ti}-\mathrm{Zr}$ alloy [106]. The $\mathrm{Ni}_{40} \mathrm{Cu}_{10} \mathrm{Ti}_{33} \mathrm{Zr}_{17}$ bulk composite alloy produced by copper mold casting shows a superior combination of strength and ductility not only due to a composite effect resulting from a multiphase structure, but also due to a strain-induced martensitic transformation [106]. The high ultimate strength of $2000 \mathrm{MPa}$ and yield stress of $650 \mathrm{MPa}$ is paired with enhanced ductility estimated at $15 \%$ compressive strain. The microstructural investigations revealed the presence of the austenitic cP2 cubic $(\mathrm{Ni}, \mathrm{Cu})(\mathrm{Ti}, \mathrm{Zr})$ phase embedded in the glassy matrix in the as-cast alloy, while mP4 martensitic $(\mathrm{Ni}, \mathrm{Cu})(\mathrm{Ti}, \mathrm{Zr})$ phase (both phases are NiTi-type) which contains other alloying elements forming solid solution is formed in the course of plastic deformation. These crystals further act as strong barriers for shear band propagation, promoting increase in stress and subsequent shear band formation and branching, thus extending the ductility and preventing a premature brittle fracture. 
Unlike common observations of serrated plastic flow associated with the large scale shear bands in monolithic metallic glasses, propagation of the shear bands in the studied alloy does not lead to the stress drops, although the shear bands were readily seen on the lateral surface of the samples tested to fracture in addition to multiple slip bands linked to each cP2 crystalline grain. By analogy with deformation-induced martensitic transformations, one can suppose that the formation of the $\mathrm{mP} 4$ martensitic phase initiates within the $\mathrm{cP} 2$ crystalline phase $[107,108]$. The most of plastic deformation attained at stresses below $1400 \mathrm{MPa}$ is transformation-aided. At the second stage of plastic deformation, there is an increasing strain hardening and intensive formation of shear bands and slip markings near the fracture surface.

\section{Deformation of Bulk Metallic Glasses at Cryogenic Temperature}

Low-temperature measurements have also been performed [109-111] and demonstrated the increase in the maximum compressive stress with decreasing testing temperature. The stress-strain diagrams for the typical glassy $\mathrm{Zr}_{64.13} \mathrm{Ni}_{10.12} \mathrm{Cu}_{15.75} \mathrm{Al}_{10}$ alloy tested at room temperature and close to boiling liquid nitrogen $\left(\mathrm{LN}_{2}\right)$ temperature are shown in Figure 5. The sample tested in liquid nitrogen exhibits notably higher compression strength compared to the sample tested at room temperature.

Figure 5. Stress-strain diagrams of $\mathrm{Zr}_{64.13} \mathrm{Ni}_{10.12} \mathrm{Cu}_{15.75} \mathrm{Al}_{10}$ glassy alloy tested at room temperature and close to boiling $\mathrm{LN}_{2}$ temperature (the sample which showed the maximum strength). The data is taken from Reference 111.

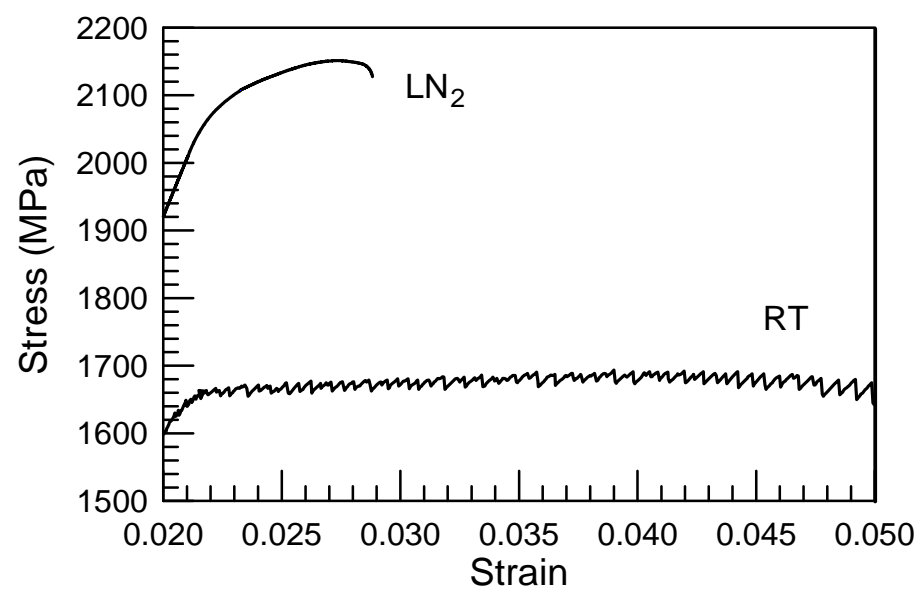

The samples tested in $\mathrm{LN}_{2}$ to different degree of deformation still exhibited formation of the localized shear deformation bands (Figure 6). Although, the stress-strain curves of the BMGs studied at room temperature (Figures 2 and 5) reveal regular stress drops the serrations do not show up (at least up to the sensitivity of the experimental setup) during testing at cryogenic temperatures even in a close-up view of the stress-strain curve of Figure 5. The samples tested in $\mathrm{LN}_{2}$ show a moderate shear plasticity while the mirror looking cleavage-like areas on the fracture surface are mixed up with typical vein patterns in nearly equal proportions like it is shown in Figure 4 for the sample tested at room temperature. 
Figure 6. SEM image in secondary electrons of the lateral surface of the $\mathrm{Zr}_{64.13} \mathrm{Ni}_{10.12} \mathrm{Cu}_{15.75} \mathrm{Al}_{10}$ glassy alloy sample after mechanical test at boiling $\mathrm{LN}_{2}$ temperature.

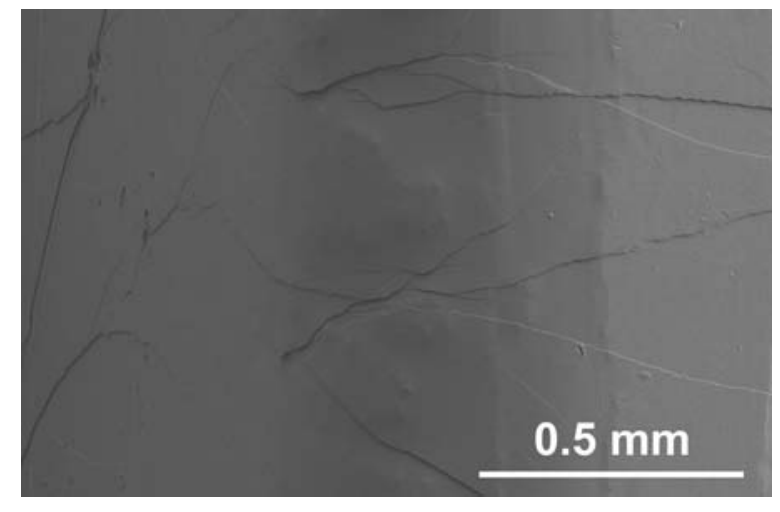

The mechanical behavior and the kinetics of shear deformation in bulk metallic glassy alloys were also investigated at room and liquid nitrogen temperature using the acoustic emission technique. It was demonstrated that the intensive acoustic emission reflecting the activity of strongly localized shear bands at room temperature vanishes at the transition from serrated to non-serrated plastic flow at $\mathrm{LN}_{2}$ temperature [112]. The disappearance of acoustic emission signals clearly suggests that the shear band propagation velocity significantly decreases at low temperature likely owing to the increased viscosity of the deforming regions.

\section{Strain-Rate Sensitivity}

While the strain-rate sensitivity (SRS) of polycrystalline alloys is generally positive (except for special cases) [113], for bulk metallic glasses (BMGs) different results were reported. A negative SRS was reported for $\mathrm{Zr}_{57} \mathrm{Ti}_{5} \mathrm{Cu}_{20} \mathrm{Ni}_{8} \mathrm{Al}_{10}$ alloy at strain rates ranging from $10^{-4}$ to $3 \cdot \times 10^{3} \mathrm{~s}^{-1}$ [114]. In addition, a negative value was obtained [115] for a similar alloy composition, e.g., $\mathrm{Zr}_{52.5} \mathrm{Ti}_{5} \mathrm{Cu}_{17.9} \mathrm{Ni}_{14.6} \mathrm{Al}_{10}$ (Vit105) and for Vit105-based composite, at strain rates of $3.3 \cdot \times 10^{-4}$ and $3.7 \cdot \times 10^{-3} \mathrm{~s}^{-1}$. In Zr-based metallic-glass coatings with micrometer-scale thickness for the shallow indentation, in which the substrate effect can be neglected, the increase of the penetration rate also leads to the decrease of the hardness [116]. At the same time, nanoindentation studies indicate positive SRS parameter values [117].

In order to illustrate strain-rate sensitivity of $\mathrm{BMG}$ alloys, the $\mathrm{Zr}_{65} \mathrm{Cu}_{20} \mathrm{Fe}_{5} \mathrm{Al}_{10}$ rod (as one of relatively ductile BMG alloys) glassy samples were tested at room temperature and the strain rate was suddenly changed upon deformation.

Figure 7 shows the true stress-plastic strain curves calculated from engineering stress values. After an initial region of apparent strain hardening, the magnitude of the stress drops increases slightly. The value of strain rate sensitivity (SRS) parameter $(\mathrm{m})$ has been calculated from the true stress-strain curves according to the relationship:

$$
m=\left(\frac{\partial \ln \sigma}{\partial \ln \dot{\varepsilon}}\right)_{\varepsilon, T}
$$


where $\sigma$ is the flow stress and $\dot{\mathcal{E}}$ is the strain rate. It is important to note that the strain rate changes have been performed in the regions where the stress-strain curves are generally linear which may correspond to the formation of multiple shear bands and macroscopically homogeneous deformation of the sample.

Figure 7. A part of the true stress-plastic strain curve (elastic strain is subtracted) obtained at the strain rates of $5 \times 10^{-3}$ and $5 \times 10^{-2} \mathrm{~s}^{-1}$. The data is taken from Reference [118] with permission of Elsevier.

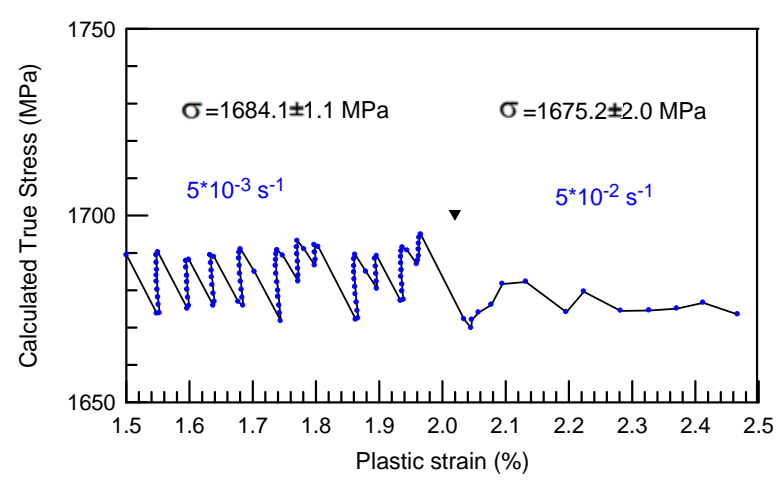

The mean and maximum flow stresses and the confidence interval (probability $p=0.95$ ) have been calculated in $0.25 \%$ plastic deformation interval using true stress values at both sides of each point of the strain rate change (Figure 7). An average maximum stress before each stress satisfied normality tests and produced similar results. Not only the flow stress but also the average maximum stress before each stress drop corresponding to a serration for each test is practically the same at each loading rate in the vicinity of the strain rate change point and the differences are practically within the confidence interval which indicates that the $\mathrm{Zr}_{65} \mathrm{Cu}_{20} \mathrm{Fe}_{5} \mathrm{Al}_{10} \mathrm{BMG}$ is strain rate insensitive ( $\left.\mathrm{m} \sim 0\right)$ in the range of strain rates from $5 \cdot \times 10^{-6}$ to $5 \cdot \times 10^{-4} \mathrm{~s}^{-1}$. Between $5 \times 10^{-4}$ and $5 \times 10^{-3} \mathrm{~s}^{-1}$ the average flow stress is similar, $1684.4 \pm 0.5 \mathrm{MPa}$ and $1685.2 \pm 1.6 \mathrm{MPa}$, respectively, and the difference is within the confidence interval. It indicates that the alloy is not strain rate sensitive at these conditions. However, when the strain rate increases from $5 \times 10^{-3}$ to $5 \times 10^{-2} \mathrm{~s}^{-1}$ the average flow stress meaningfully decreases from $1684.1 \pm 1.1$ to $1675 \pm 2.0 \mathrm{MPa}$, and according to Equation 1 the SRS is negative $(\mathrm{m}=-0.0026)$.

From the statistical analysis of the mean and maximum flow stress at each loading rate it has been calculated that the alloy does not exhibit SRS within the confidence interval from $5 \times 10^{-6}$ to $5 \times 10^{-3} \mathrm{~s}^{-1}$. The SRS values derived by using the confidence interval are smaller $(\mathrm{m} \sim 0)$ than the value of $\mathrm{m}$ reported for $\mathrm{Zr}_{52.5} \mathrm{Ti}_{5} \mathrm{Cu}_{17.9} \mathrm{Ni}_{14.6} \mathrm{Al}_{10}$ at room temperature (e.g., about -0.002) by [119] and $\mathrm{Cu}_{50} \mathrm{Zr}_{50} \mathrm{BMG}$ by [120]. However, the SRS becomes meaningfully negative when the strain rate increases from $5 \times 10^{-3} \mathrm{~s}^{-1}$ to $5 \times 10^{-2} \mathrm{~s}^{-1}$ because the strain rate is so fast that the relaxation time is not enough to build up the stress which explains the decrease in the flow stress.

Despite on the minimum strain rate at which this alloy exhibits a negative SRS value is $5 \times 10^{-3} / 5 \times 10^{-2} \mathrm{~s}^{-1}$ it should be taken into account that it depends on the loading conditions. For example, while $\mathrm{Zr}_{52.5} \mathrm{Ti}_{5} \mathrm{Cu}_{17.9} \mathrm{Ni}_{14.6} \mathrm{Al}_{10}$ one exhibits negative SRS in compression by Reference [121] it is strain rate insensitive under indentation by Reference [122]. The different behavior could be 
mainly attributed to the stress state, which is closer to three-axial compression when tested by indentation. Moreover, there is a strong size effect on deformation behavior upon indentation in which the deformed volume is significantly smaller while local plastic deformation is larger than in compression.

\section{In situ Room-Temperature Tensile Deformation in TEM}

At the same time, metallic glasses are proven to deform homogeneously on nanoscale. Plastic deformation in metallic glasses has been performed using the in-situ TEM technique [123-125]. After initial observation, the beam current was reduced and the sample deformed in a straining holder in tension. This is an important precaution to prevent electron-beam heating of the sample upon deformation. This procedure (straining and subsequent observation) has been repeated several times until some cracks had become apparent. High-resolution in-situ TEM investigation showed that the $\mathrm{Zr}_{65} \mathrm{Ni}_{10} \mathrm{Cu}_{5} \mathrm{Al}_{7.5} \mathrm{Pd}_{12.5}$ ribbon sample retains its glassy structure after in-situ deformation and crack propagation (Figure 8). No nanocrystallization was observed even near the crack.

Figure 8. High-resolution TEM image obtained upon in-situ deformation in a microscope near the crack in the $\mathrm{Zr}_{65} \mathrm{Ni}_{10} \mathrm{Cu}_{5} \mathrm{Al}_{7.5} \mathrm{Pd}_{12.5}$ glassy alloy.

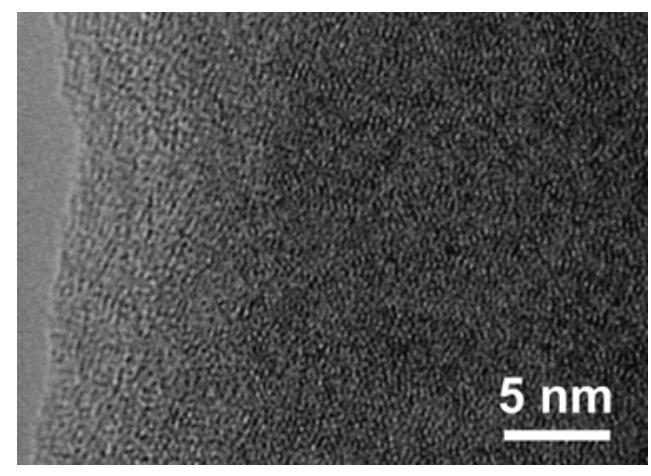

The homogeneous deformation of the thinned $\mathrm{Zr}_{65} \mathrm{Ni}_{10} \mathrm{Cu}_{5} \mathrm{Al}_{7.5} \mathrm{Pd}_{12.5}$ alloy is clearly seen in front of the crack tip upon loading. The deformation rate estimated by crack opening speed was quite low-about tens of nanometers per second or even less. A narrow featureless deformation zone forms ahead of the crack tip, with the brightness different from that in the rest of the sample. However, this zone is much wider than the typical $(10-20 \mathrm{~nm})$ width of a shear band. Similar results were obtained for submicron (about $200 \mathrm{~nm}$ ) thick $\mathrm{Zr}_{52.5} \mathrm{Cu}_{17.9} \mathrm{Al}_{10} \mathrm{Ni}_{14.6} \mathrm{Ti}_{5}$ alloy [126].

The in situ experiments demonstrate a fundamental possibility of a homogeneous-like like plastic flow to occur in a localized area of glassy metal thin foil without aid of temperature. Indeed, any deformation induced heating effects can be neglected. According to recent calculations the thermal energy release, and thus a rise in the sample temperature, depends on the deformation rate and shear offset, in addition to the thermal conductivity and the strength of the glassy phase [127-129]. However, the deformation areas observed in the ribbon sample tested in situ are much wider compared to the highly localized deformation bands observed in bulk glassy sample. Thus, no significant heating could have taken place as the heat generated upon the deformation is dissipated over a larger volume. 


\section{Effect of Cyclic and Long-Term Creep Deformation in the Elastic Region}

The beginning of nanocrystallization was observed in the $\mathrm{Zr}_{62.5} \mathrm{Fe}_{5} \mathrm{Cu}_{22.5} \mathrm{Al}_{10}$ bulk metallic glassy cubic samples (edge size equal to $4 \mathrm{~mm}$ ) under low stress of $586 \pm 242 \mathrm{MPa}$ in the elastic region while no such an effect was seen in the rod shaped samples of $2 \mathrm{~mm}$ in diameter [130]. This alloy also showed phase separation on heating prior to crystallization [76,131]. Later the $\mathrm{Zr}_{62.5} \mathrm{Fe}_{5} \mathrm{Cu}_{22.5} \mathrm{Al}_{10}$ BMG samples of $3 \mathrm{~mm}$ in diameter and $3 \mathrm{~mm}$ in height were cyclically loaded at higher stresses of $800 \pm 200 \mathrm{MPa}$ and $1000 \pm 200 \mathrm{MPa}$, which are still significantly lower than the Yield Strength. It was found that kinetically frozen anelastic deformation accumulates at room temperature and causes crystallization of metallic glassy phase. There was an increase in the crystallization enthalpy after cyclic loading for 1000 cycles at $1000 \pm 200 \mathrm{MPa}$ from $44 \mathrm{~J} / \mathrm{g}$ to $48 \mathrm{~J} / \mathrm{g}$ is likely connected with the formation of the nuclei of non-equilibrium phase which together with the residual glassy phase may represent a state with higher free energy. An anelastic contribution can arise from localized viscous flow of structural defects [132,133]. The volume changes were locally accommodated by cumulative anelastic deformation and led to subsequent partial nanocrystallization of the glass.

Uniaxial compression of a BMG close to Yield Strength induced creep of the samples, accompanied by an increase in the stored heat of relaxation [134]. The sample exhibited an increase in compressive plasticity on the subsequent test [135]. This creep is homogeneous and leads to decreases in density and in elastic moduli. The increase in heat of relaxation and in plasticity in BMGs resulting from static loading are reported to depend on the atomic packing density [136].

\section{Conclusive Remarks}

In general, bulk metallic glasses (glassy alloys) have high strength about two times higher than that of their crystalline counterparts but poor plasticity. However, the selected bulk metallic glasses and crystal-glassy composites on their base exhibit both high strength and good room-temperature plasticity. Moreover, in the case of the Pd-based alloys their plasticity can be drastically improved by fluxing with $\mathrm{B}_{2} \mathrm{O}_{3}$. On deformation, bulk metallic glasses exhibit periodic drops of stress indicating so-called serrated flow, while no such a behavior is seen on testing at cryogenic temperature and in case of various composite samples. Disappearance of the stress drops may be connected with a more homogeneous deformation. On the other hand, submicron-size $\mathrm{Zr}_{65} \mathrm{Ni}_{10} \mathrm{Cu}_{5} \mathrm{Al}_{7.5} \mathrm{Pd}_{12.5}$ glassy samples demonstrate homogeneous deformation at room temperature. Some metallic glasses which have pre-existing nuclei demonstrate deformation-induced nanocrystallization within heavily deformed areas while alloys which exhibit nucleation and growth behavior on heating are less predisposed to demonstrate such a behavior. The nanocrystallization was also observed upon cyclic loading. Low-temperature measurements demonstrated the increase in the maximum compressive stress with decreasing testing temperature and absence of stress drops. BMGs showed negative SRS in compression. In addition, metallic glasses were found to deform homogeneously on nanoscale which makes them attractive for applications in micro-electro-mechanical systems. 


\section{Acknowledgement}

This work was supported by "World Premier International Research Center (WPI) Initiative for Atoms, Molecules and Materials" and by Russian Ministry of Education and Science of Russia, project 14.A18.21.1202.

\section{References}

1. Inoue, A. High strength bulk amorphous alloys with low critical cooling rates. Mater. Trans. JIM 1995, 36, 866-875.

2. Johnson, W.L. Bulk glass-forming metallic alloys: Science and technology. MRS Bull 1999, 24, 42-56.

3. Inoue, A. Stabilization of metallic supercooled liquid and bulk amorphous alloys. Acta Mater. 2000, 48, 279-306.

4. Argon, A.S. Mechanisms of inelastic deformation in metallic lasses. Phys. Chem. Solids 1982, 43, 945.

5. Liu, F.X.; Liaw, P.K.; Wang, G.Y.; Chiang, C.L.; Smith, D.A.; Rack, P.D.; Chu, J.P.; Buchanan, R.A. Specimen-geometry effects on mechanical behavior of metallic glasses. Intermetallics 2006, 14, 1014.

6. Inoue, A.; Shen, B.; Koshiba, H.; Kato, H.; Yavari, A.R. Cobalt-based bulk glassy alloy with ultrahigh strength and soft magnetic properties. Nat. Mater. 2003, 2, 661.

7. Wang, J.; Li, R.; Hua, N.; Zhang, T. Co-based ternary bulk metallic glasses with ultrahigh strength and plasticity. J. Mater. Res. 2011, 26, 16, 2072-2079

8. Amiya, K.; Inoue, A. Fe-(Cr, Mo)-(C, B)-Tm bulk metallic glasses with high, strength and high glass-forming ability. Rev. Adv. Mater. Sci. 2008, 18, 27.

9. Louzguine, D.V.; Inoue, A. Structural and thermal investigations of a high-strength Cu-Zr-Ti-Co bulk metallic glass. Philos. Mag. Lett. 2003, 83, 191-196.

10. Inoue, A.; Yamaguchi, H.; Zhang, T.; Masumoto, T. Al-La-Cu amorphous alloys with a wide supercooled liquid region. Mater. Trans. JIM 1990, 31, 104-109.

11. Zhang, W.; Inoue, A. Synthesis, thermal stability and mechanical properties of Cu-based bulk glassy alloys. World Bulk Met. Glass. Compos. 2007, 201-230.

12. Inoue, A.; Zhang, W.; Saida, J. Synthesis and fundamental properties of Cu-based bulk glassy alloys in binary and multi-component systems. Mater. Trans. 2004, 45, 4, 1153-1162.

13. Inoue, A.; Zhang, W.; Zhang, T.; Kurosaka, K. Formation and mechanical properties of Cu-Hf-Ti bulk glassy alloys. J. Mater. Res. 2001, 16, 2836-2844.

14. Inoue, A.; Zhang, W.; Zhang, T.; Kurosaka, K. High-strength Cu-based bulk glassy alloys in $\mathrm{Cu}-\mathrm{Zr}-\mathrm{Ti}$ and $\mathrm{Cu}-\mathrm{Hf}-\mathrm{Ti}$ ternary systems. Acta Mater. 2001, 49, 2645-2652.

15. Zhang, W.; Inoue, A. High glass-forming ability and good mechanical properties of new bulk glassy alloys in $\mathrm{Cu}-\mathrm{Zr}-\mathrm{Ag}$ ternary system. J. Mater. Res. 2006, 21, 234-241.

16. Kim, K.B.; Das, J.; Lee, M.H.; Yi, S.; Fleury, E.; Zhang, Z.F.; Wang, W.H.; Eckert, J. Propagation of shear bands in a $\mathrm{Cu}_{47.5} \mathrm{Zr}_{47.5} \mathrm{Al}_{5}$ bulk metallic glass. J. Mater. Res. 2008, 23, 6-12. 
17. Inoue, A.; Zhang, W. Formation, thermal stability and mechanical properties of $\mathrm{Cu}-\mathrm{Zr}-\mathrm{Al}$ bulk glassy alloys. Mater. Trans. 2002, 43, 2921-2925.

18. Zhang, Q.; Zhang, W.; Xie, G.; Inoue, A. Glass-forming ability and mechanical properties of the ternary $\mathrm{Cu}-\mathrm{Zr}-\mathrm{Al}$ and quaternary $\mathrm{Cu}-\mathrm{Zr}-\mathrm{Al}-\mathrm{Ag}$ bulk metallic glasses. Mater. Trans. 2007, 48, $1626-1630$.

19. Zhang, W.; Inoue, A. Formation and mechanical strength of new Cu-based bulk glassy alloys with large supercooled liquid region. Mater. Trans. 2004, 45, 1210-1213.

20. Zhang, Q.; Zhang, W.; Inoue, A. Bulk metallic glass formation near a quaternary Cu-Zr-Ti-Al eutectic point. Mater. Trans. 2006, 47, 2804-2807.

21. Chen, J.; Zhang, Y.; He, J.P; Yao, K.F.; Wei, B.C.; Chen, G.L. Metallographic analysis of $\mathrm{Cu}-\mathrm{Zr}-\mathrm{Al}$ bulk amorphous alloys with yttrium addition. Scr. Mater. 2006, 54, 1351-1355.

22. Bhatt, J.; Wu, J.; Xia, J.; Wand, Q.; Dong, C.; Murty, B.S. Optimization of bulk metallic glass forming compositions in $\mathrm{Zr}-\mathrm{Cu}-\mathrm{Al}$ system by thermodynamic modeling. Intermetallics 2007, 15, 716-721.

23. Zhang, W.; Inoue, A. Cu-based bulk glass formation in the $\mathrm{Cu}-\mathrm{Zr}-\mathrm{Ga}$ alloy system and their mechanical properties. Mater. Trans. 2004, 45, 532-535.

24. Men, H.; Fu, J.; Ma, C.; Pang, S.; Zhang, T. Bulk glass formation in ternary Cu-Zr-Ti system. J. Univ. Sci. Technol. Beijing 2007, 14, 19.

25. Chen, D.; Takeuchi, A.; Inoue, A. Gd-Co-Al and Gd-Ni-Al bulk metallic glasses with high glass forming ability and good mechanical properties. Mater. Sci. Eng. 2007, 457, 226-230.

26. Chen, D.; Takeuchi, A.; Inoue, A. Gd-Ni-Al bulk glasses with great glass-forming ability and better mechanical properties. J. Mater. Sci. 2007, 42, 8662-8666.

27. Inoue, A.; Zhang, T.; Masumoto, T. Al-La-Ni amorphous alloys with a wide supercooled liquid region. Mater. Trans. JIM 1989, 30, 965-972.

28. Inoue, A.; Kato, A.; Zhang, T.; Kim, S.; Masumoto, T. Mg-Cu-Y amorphous alloys with high mechanical strengths produced by metallic mold casting method. JIM 1991, 32, 609-616.

29. Park, E.S.; Chang, H.J.; Kim, D.H. Mg-rich Mg-Ni-Gd ternary bulk metallic glasses with high compressive specific strength and ductility. J. Mater. Res. 2007, 22, 334-338.

30. Kim, S.G.; Inoue, A.; Masumoto, T. High mechanical strengths of Mg-Ni-Y and Mg-Cu-Y amorphous alloys with significant supercooled liquid region. Mater. Trans. JIM 1990, 31, 929-934.

31. Inoue, A.; Zhang, T.; Masumoto, T. Zr-Al-Ni amorphous alloys with high class transition temperature and significant supercooled liquid region. Mater. Trans. JIM 1990, 31, 177-183.

32. Yokoyama, Y.; Yamasaki, T.; Liaw, P.K.; Inoue, A. Relations between the thermal and mechanical properties of cast Zr-TM-Al (TM: Cu, Ni, or Co) bulk glassy alloys. Mater. Trans. 2007, 48, 1846-1849.

33. Wada, T.; Zhang, T.; Inoue, A. Formation, thermal stability and mechanical properties in Zr-Al-Co bulk glassy alloys. JIM 2002, 43, 2843-2846.

34. Yokoyama, Y.; Kobayashi, A.; Fukaura, K.; Inoue, A. Oxygen embrittlement and effect of the addition of Ni element in a bulk amorphous Zr-Cu-Al alloy. Mater. Trans. 2002, 43, 571-574. 
35. Yokoyama, Y.; Liaw, P.K.; Nishijima, M.; Hiraga, K.; Buchanan, R.A.; Inoue, A. Fatigue-strength enhancement of cast $\mathrm{Zr}_{50} \mathrm{Cu}_{40} \mathrm{Al}_{10}$ glassy alloys. Mater. Trans. 2006, 47, 1286-1293.

36. Yokoyama, Y.; Yamasaki, T.; Liaw, P.K.; Inoue, A. Relations between the thermal and mechanical properties of cast $\mathrm{Zr}-\mathrm{TM}-\mathrm{Al}(\mathrm{TM}$ : $\mathrm{Cu}, \mathrm{Ni}$, or $\mathrm{Co}$ ) bulk glassy alloys. Evolution of mechanical properties of cast $\mathrm{Zr}_{50} \mathrm{Cu}_{40} \mathrm{Al}_{10}$ glassy alloys by structural relaxation. Mater. Trans. 2005, 46, 2755-2761.

37. Inoue, A.; Zhang, W. New bulk glassy Ni-based alloys with high strength of $3000 \mathrm{MPa}$. Mater. Trans. 2002, 43, 708-711.

38. Jing, Q.; Zhang, Y.; Wang, D.; Li, Y. A study of the glass forming ability in Zr-Ni-Al alloys. Mater. Sci. Eng. 2006, 441, 106-111.

39. Inoue, A.; Zhang, T.; Masumoto, T. Amorphous Zr-Al-TM (TM = Co,Ni,Cu) alloys with significant supercooled liquid region of over 100 K. Mater. Trans. JIM 1991, 32, 1005-1010.

40. Yi, S.; Park, T.G.; Kim, D.H. Ni-based bulk amorphous alloys in the Ni-Ti-Zr-(Si, Sn) system. J. Mater. Res. 2000, 15, 11.

41. Zhang, B.; Zhao, D.Q.; Pan, M.X.; Wang, R.J.; Wang, W.H. Amorphous metallic plastic. Acta Mater. 2006, 54, 3025-3032.

42. Koshiba, H.; Inoue, A. Preparation and magnetic properties of Co-based bulk glassy alloys. Mater. Trans. 2001, 42, 2572-2575.

43. Qin, C.; Zhang, W.; Kimura, H.; Inoue, A. Excellent mechanical properties of Cu-Hf-Ti-Ta bulk glassy alloys containing in situ dendrite Ta-based BCC phase. Mater. Trans. 2004, 45, 2936-2940.

44. Zhang, W.; Zhang, Q.; Qin, C.; Inoue, A. Synthesis and properties of Cu-Zr-Ag-Al glassy alloys with high glass-forming ability. Mater. Sci. Eng. 2008, 148, 92-96.

45. Inoue, A.; Zhang, T.; Kurosaka, K.; Zhang, W. High strength Cu-based bulk glassy alloys in Cu-Zr-Ti-Be system. Mater. Trans. 2001, 42, 1800-1804.

46. Zhang, T.; Kurosaka, K.; Inoue, A. Thermal and mechanical properties of Cu-based Cu-Zr- Ti-Y bulk glassy alloys. Mater. Trans. 2001, 42, 2042-2045.

47. Makino, A.; Kubota, T.; Chang, C.; Makabe, M.; Inoue, A. FeSiBP bulk metallic glasses with unusual combination of high magnetization and high glass-forming ability. Mater. Trans.2007, 48, 3024-3027.

48. Zhang, W.; Jia, F.; Inoue, A. Formation and properties of new La-based bulk glassy alloys with diameters up to centimeter order. Mater. Trans. 2007, 48, 68-73.

49. Yuan, G.; Amiya, K.; Inoue, A. Structural-relaxation, glass-forming ability and mechanical properties of Mg-Cu-Ni-Gd alloys. J. Non Cryst. Solids 2005, 351, 729-735.

50. Yuan, G.; Zhang, T.; Inoue, A. Thermal stability, glass-forming ability and mechanical properties of Mg-Y-Zn-Cu glassy alloys. Mater. Trans 2003, 44, 2271-2275.

51. Inoue, A.; Zhang, W.; Zhang, T. Thermal stability and mechanical strength of bulk glassy Ni-Nb-Ti-Zr alloys. Mater. Trans. 2002, 43, 1952-1956.

52. Shen, B.; Inoue, A. Glass transition behavior and mechanical properties of Ni-Si-B-based glassy alloys. Mater. Trans. 2003, 44, 1425-1428. 
53. Arai, K.; Zhang, W.; Jia, F.; Inoue, A. Synthesis and thermal stability of new Ni-based bulk glassy alloy with excellent mechanical properties. Mater. Trans. 2006, 47, 2358-2362.

54. Kim, J.H.; Park, J.S.; Lim, H.K.; Kim, W.T.; Kim, D.H. Heating and cooling rate dependence of the parameters representing the glass forming ability in bulk metallic glasses. J. Non Cryst. Solids 2005, 351, 1433-1440.

55. Liu, L.; Inoue, A.; Zhang, T. Formation of bulk Pd-Cu-Si-P glass with good mechanical properties. Mater. Trans. 2005, 46, 376-378.

56. Takenaka, K.; Wada, T.; Nishiyama, N.; Kimura, H.; Inoue, A. New Pd-based bulk glassy alloys with high glass-forming ability and large supercooled liquid region. Mater. Trans. 2005, 46, $1720-1724$.

57. Inoue, A.; Nishiyama, N.; Kimura, H. Preparation and thermal stability of bulk amorphous $\mathrm{Pd}_{40} \mathrm{Cu}_{30} \mathrm{Ni}_{10} \mathrm{P}_{20}$ alloy cylinder of $72 \mathrm{~mm}$ in diameter. Mater. Trans. JIM 1997, 38, 179-183.

58. Zhang, T.; Inoue, A. Thermal and mechanical properties of Ti-Ni-Cu-Sn amorphous alloys with a wide supercooled liquid region before crystallization. Mater. Trans. JIM 1998, 39, 1001-1006.

59. Wada, T.; Zhang, T.; Inoue, A. Formation and high mechanical strength of bulk glassy alloys in Zr-Al-Co-Cu system. Mater. Trans. 2003, 44, 1839-1844.

60. Saida, J.; Kato, H.; Deny, A.; Setyawan, H.; Yoshimi, K.; Inoue, A. Deformation-induced nanoscale dynamic transformation studies in $\mathrm{Zr}$-Al-Ni-Pd and $\mathrm{Zr}-\mathrm{Al}-\mathrm{Ni}-\mathrm{Cu}$ bulk metallic glasses. Mater. Trans. 2007, 48, 1327-1335.

61. Yokoyama, Y.; Inoue, A. Compositional dependence of thermal and mechanical properties of quaternary $\mathrm{Zr}-\mathrm{Cu}-\mathrm{Ni}-\mathrm{Al}$ bulk glassy alloys. Mater. Trans. 2007, 48, 1282-1287.

62. Zhang, Q.S.; Zhang, W.; Louzguine-Luzgin, D.V.; Inoue, A. High glass-forming ability and unusual deformation behavior of new $\mathrm{Zr}-\mathrm{Cu}-\mathrm{Fe}-\mathrm{Al}$ bulk metallic glasses. Mater. Sci. Forum 2010, 654-656, 1042-1045.

63. Conner, R.D.; Li, Y.; Nix, W.D.; Johnson, W.L. Shear band spacing under bending of Zr-based metallic glass plates. Acta Mater. 2004, 52, 2429-2434.

64. Donovan, P.E.; Stobbs, W.M. The structure of shear bands in metallic glasses. Acta Metall. 1981, 29, 1419-1436.

65. Chen, H.S. Plastic flow in metallic glasses under compression. Scr. Metar. 1973, 7, 931-935.

66. Mear, F.O.; Wada, T.; Louzguine-Luzgin, D.V.; Inoue, A. Highly inhomogeneous compressive plasticity in nanocrystal-toughened Zr-Cu-Ni-Al bulk metallic glass. Philos. Mag. Lett. 2009, 89, 276-281.

67. Yavari, A.R.; Lewandowski, J.J.; Eckert, J. Mechanical properties of bulk metallic glasses. MRS Bull. 2007, 32, 635-638.

68. Pan, J.; Chan, K.C.; Chena, Q.; Liu, L. Enhanced plasticity by introducing icosahedral medium-range order in $\mathrm{ZrCuNiAl}$ metallic glass. Intermetallics 2012, 24, 79-83.

69. Chen, N.; Louzguine-Luzgin, D.V.; Xie, G.Q.; Wada, T.; Inoue, A. Influence of minor Si addition on glass forming ability and mechanical properties of $\mathrm{Pd}_{40} \mathrm{Ni}_{40} \mathrm{P}_{20}$ alloy. Acta Mater.2009, 57, 2775-2780.

70. Chen, N.; Pan, D.; Louzguine-Luzgin, D.V.; Xie, G.Q.; Chen, M.W.; Inoue, A. Improved thermal stability and ductility of flux-treated $\mathrm{Pd}_{40} \mathrm{Ni}_{40} \mathrm{Si}_{4} \mathrm{P}_{16}$ BMG. Scr. Mater. 2010, 62, 17-20. 
71. Zhang, Q.S.; Zhang, W.; Xie, G.Q.; Louzguine-Luzgin, D.V.; Inoue, A. Stable flowing of localized shear bands in soft bulk metallic glasses. Acta Mater. 2010, 58, 904-909.

72. Kato, H.; Saida, J.; Inoue, A. Influence of hydrostatic pressure during casting on as cast structure and mechanical properties in $\mathrm{Zr}_{65} \mathrm{Al}_{7.5} \mathrm{Ni}_{10} \mathrm{Cu}_{17.5-x} \mathrm{Pd}_{x}(x=0,17.5)$ alloys. Scr. Mater. 2004, 51, 1063-1068.

73. Schroers, J.; Johnson, W.L. Ductile bulk metallic glass. Phys. Rev. Lett. 2004, 93, 255506-255510.

74. Lewandowski, J.J.; Wang, W.H.; Greer, A.L. Intrinsic plasticity or brittleness of metallic glasses. Philos. Mag. Lett. 2005, 85, 77.

75. Madge, S.V.; Louzguine-Luzgin, D.V.; Lewandowski, J.J.; Greer, A.L. Toughness, extrinsic effects and Poisson's ratio of bulk metallic glasses. Acta Mater. 2012, 60, 4800-4809.

76. Louzguine-Luzgin, D.V.; Xie, G.; Zhang, Q.; Inoue, A. Effect of Fe on the glass-forming ability, structure and devitrification behavior of $\mathrm{Zr}-\mathrm{Cu}-\mathrm{Al}$ bulk glass-forming alloys. Philos. Mag. 2010, 90, 1955-1968.

77. Wright, W.J.; Schwarz, R.B.; Nix, W.D. Localized heating during serrated plastic flow in bulk metallic glasses. Mater. Sci. Eng. 2001, 319-321, 229-232.

78. Dalla Torre, F.H.; Dubach, A.; Siegrist, M.E.; Löffler, J.F. Negative strain rate sensitivity in bulk metallic glass and its similarities with dynamic strain aging effect during deformation. Appl. Phys. Lett. 2006, 89, 091918.

79. Yu, H.B.; Wang, W.H.; Zhang, J.L.; Shek, C.H.; Bai, H.Y. Statistic analysis of the mechanical behavior of bulk metallic glasses. Adv. Eng. Mater. 2009, 11, 370-375.

80. Liu, F.X.; Liaw, P.K.; Wang, G.Y.; Chiang, C.L.; Smith, D.A.; Rack, P.P.D; Chu, P.P.; Buchanan, R.A. Specimen-geometry effects on mechanical behavior of metallic glasses. Intermetallics 2006, 14, 1014-1018.

81. Uchic, M.D.; Dimiduk, D.M.; Florando, N.; Nix, W.D. Sample dimensions influence strength and crystal plasticity. Science 2004, 305, 986-989.

82. Wang, G.; Feng, Q.; Yang, B.; Jiang, W.; Liaw, P.K.; Liu, C.T.; Thermographic studies of temperature evolutions in bulk metallic glasses. Intermetallics 2012, 30, 1-11.

83. Wang, D.; Li, Y.; Sun, B.B.; Sui, M.L.; Lu, K.; Ma, E. Bulk metallic glass formation in the binary Cu-Zr system. Appl. Phys. Lett. 2004, 84, 4029.

84. Yokoyama, Y.; Fujita, K.; Yavari, A.R.; Inoue, A. Correlation between structural relaxation and shear transformation zone volume of a bulk metallic glass. Philos. Mag. Lett. 2009, 89, 322.

85. Inoue, A.; Zhang, W.; Tsurui, T.; Yavari, A.R.; Greer, A.L. Unusual room-temperature compressive plasticity in nanocrystal-toughened bulk copper-zirconium glass. Philos. Mag. Lett. 2005, 85, 221-229.

86. Louzguine, D.V.; Kato, H.; Inoue, A. High-strength Cu-based crystal-glassy composite with enhanced ductility. Appl. Phys. Lett. 2004, 84, 1088-1089.

87. Das, J.; Tang, M.B.; Kim, K.B.; Theissmann, R.; Baier, F.; Wang, W.H.; Eckert, J. Work-hardenable ductile bulk metallic glass. Phys. Rev. Lett. 2005, 94, 205501.

88. Mear, F.O.; Wada, T.; Louzguine-Luzgin, D.V.; Inoue, A. Structural investigations of rapidly solidified Mg-Cu-Y alloys. J. Alloy. Compd. 2010, 496, 149-154. 
89. Hajlaoui, K.; Yavari, A.R.; LeMoulec, A.; Botta, W.J.; Vaughan, F.G.; Das, J.; Greer, A.L.; Kvick, A. Plasticity induced by nanoparticle dispersions in bulk metallic glasses. J. Non Cryst. Solids 2007, 353, 327-331.

90. Saida, J.; Kato, H.; Setyawan, A.D.H.; Inoue, A. Characterization and properties of nanocrystal-forming Zr-based bulk metallic glasses. Rev. Adv. Mater. Sci. 2005, 10, 34-38.

91. Louzguine-Luzgin, D.V.; Zeng, Y.; Setyawan, A.D.H.; Nishiyama, N.; Kato, H.; Saida, J.; Inoue, A. Corrosion resistance and XPS studies of Ni-rich Ni-Pd-P-B bulk glassy alloys. J. Mater. Res 2007, 22, 1087-1090.

92. Gao, M.C.; Hackenberg, R.E.; Shiflet, G.J. Deformation-induced nanocrystal precipitation in Al-base metallic glasses. Mater. Trans. 2001, 42, 1741-1747.

93. Jiang, W.H.; Atzmon, M. Plastic flow of a nanocrystalline/amorphous $\mathrm{Al}_{90} \mathrm{Fe}_{5} \mathrm{Gd}_{5}$ composite formed by rolling. Intermetallics 2006, 14, 962-965.

94. Louzguine-Luzgin, D.V.; Inoue, A. Comparative study of the effect of cold rolling on the structure of Al-RE-Ni-Co (RE = rare-earth metals) amorphous and glassy alloys. J. Non Cryst. Solids 2006, 352, 3903-3909.

95. Zhang, Z.F.; He, G.; Zhang, H.; Eckert, J. Rotation mechanism of shear fracture induced by high plasticity in Ti-based nano-structured composites containing ductile dendrites. Scri. Mater. 2005, 52, 945-949.

96. Dalla Torre, F.H.; Dubach, A.; Schallibaum, J.; Loffler, J.F. Shear striations and deformation kinetics in highly deformed Zr-based bulk metallic glasses. Acta Mater. 2008, 56, 4635-4646.

97. Sergueeva, A.V.; Mara, N.A.; Branagan, D.J.; Mukherjee, A.K. Strain rate effect on metallic glass ductility. Scr. Mater. 2004, 50, 1303-1307.

98. Hajlaoui, K.; Stoica, M.; LeMoulec, A.; Charlot, F.; Yavari, A.R. Fe-Nb-B bulk metallic glass with high boron content. Rev. Adv. Mater. Sci. 2008, 18, 23-26.

99. Louzguine-Luzgin, D.V.; Vinogradov, A.; Yavari, A.R.; Li, S.; Xie, G.; Inoue, A. On the deformation and fracture behaviour of a Zr-based glassy alloy. Philos. Mag. 2008, 88, 2979-2987.

100. Pampillo, C.A. Flow and fracture in amorphous alloys. J. Mater. Sci 1975, 10, 1194-1227.

101. Lewandowski, J.J.; Greer, A.L. Temperature rise at shear bands in metallic glasses. Nat. Mater. 2006, 5, 15-18.

102. Yang, B.; Morrison, M.L.; Liaw, P.P.K.; Buchanan, R.A.; Wang, G.; Liu, C.T.; Denda, M. Dynamic evolution of nanoscale shear bands in a bulk-metallic glass. Appl. Phys. Lett 2005, 86, 141904-141907.

103. Chen, N.; Louzguine-Luzgin, D.V.; Xie, G.Q.; Inoue, A. Nanoscale wavy fracture surface of a Pd-based bulk metallic glass. Appl. Phys. Lett. 2009, 94, 131906.

104. Hofmann, D.C.; Suh, J.Y.; Wiest, A.; Duan, G.; Lind, M.L.; Demetriou, M.D.; Johnson, W.L. Designing metallic glass matrix composites with high toughness and tensile ductility. Nature 2008, 451, 1085.

105. Hofmann, D.C.; Suh, J.Y.; Wiest, A.; Lind, M.L.; Demetriou, M.D.; Johnson, W.L. Development of tough, low-density titanium-based bulk metallic glass matrix composites with tensile ductility. PNAS 2008, 105, 20136. 
106. Louzguine-Luzgin, D.V.; Vinogradov, A.; Xie, G.; Li, S.; Lazarev, A.; Hashimoto, S.; Inoue, A. High-strength and ductile glassy-crystal Ni-Cu-Zr-Ti composite exhibiting stress-induced martensitic transformation. Philos. Mag. 2009, 89, 2887-2901.

107. Otsuka, K.; Wayman, C.M. Shape Memory Materials; Otsuka, K., Wayman, C.M., Eds.; Cambridge University Press: Cambridge, UK, 1998; p. 27-48.

108. Fukuda, T.; Saburi, T.; Chihara, T.; Tsuzuki, Y. Mechanism of B2-B19-B19' transformation in shape memory Ti-Ni-Cu alloys. Mater. Trans. JIM 1995, 36, 1244-1248.

109. Kawashima, A.; Zeng, Y.; Fukuhara, M.; Kurishita, H.; Nishiyama, N.; Miki, H.; Inoue, A. Mechanical properties of a $\mathrm{Ni}_{60} \mathrm{Pd}_{20} \mathrm{P}_{17} \mathrm{~B}_{3}$ bulk glassy alloy at cryogenic temperatures. Mater. Sci. Eng. 2008, 498, 475-481.

110. Tabachnikova, E.D.; Podol'ski, A.V.; Bengus, V.Z.; Smirnov, S.N.; Luzgin, D.V.; Inoue, A. Low-temperature plasticity anomaly in the bulk metallic glass $\mathrm{Zr}_{64.13} \mathrm{Cu}_{15.75} \mathrm{Ni}_{10.12} \mathrm{Al}_{10}$. Low Temp. Phys. 2008, 34, 675-677.

111. Louzguine-Luzgin, D.V.; Vinogradov, A.; Li, S.; Kawashima, A.; Xie, G.; Yavari, A.R.; Inoue, A. Deformation and fracture behavior of metallic glassy alloys and glassy-crystal composites. Metall. Mater. Trans. 2011, 42A, 1504-1510.

112. Vinogradov, A.; Lazarev, A.; Louzguine-Luzgin, D.V.; Yokoyama, Y.; Li, S.; Yavari, A.R.; Inoue, A. Propagation of shear bands in metallic glasses and transition from serrated to non-serrated plastic flow at low temperatures. Acta Mater. 2010, 58, 6736.

113. Woodford, D.A. Strain-rate sensitivity as a measure ductility. Trans. Am. Soc. Met. 1969, 62, 291-293.

114. Hufnagel, T.; Jiao, C.; Li, T.; Xing, Y.; Ramesh, L.Q. Deformation and failure of $\mathrm{Zr}_{57} \mathrm{Ti}_{5} \mathrm{Cu}_{20} \mathrm{Ni}_{8} \mathrm{Al}_{10}$ bulk metallic glass under quasi-static and dynamic compression. J. Mater. Res. 2002, 17, 1441.

115. Dalla Torre, F.H.; Dubach, A.; Siegrist, M.; Löffler, J.F. Shear striations and deformation kinetics in highly deformed Zr-based bulk metallic glasses. Appl. Phys. Lett. 2006, 89, 091918.

116. Liu, F.X.; Gao, Y.F.; Liaw, P.K. Rate-dependent deformation behavior of Zr-based metallic-glass coatings examined by nanoindentation. Metall. Mater. Trans. 2008, 39, 8, $1862-1867$.

117. Pan, D.; Chen, M.W. Rate-change instrumented indentation for measuring strain rate sensitivity. J. Mater. Res. 2009, 24, 4, 1466-1470.

118. González, S.; Xie, G.Q.; Louzguine-Luzgin, D.V.; Perepezko, J.H.; Inoue, A. Deformation and strain rate sensitivity of a Zr-Cu-Fe-Al metallic glass. Mater. Sci. Eng. 2011, 528, 3506-3512.

119. Song, S.X.; Bei, H.; Wadsworth, J.; Nieh, T.G. Flow serration in a Zr-based bulk metallic glass in compression at low strain rates. Intermetallics 2008, 16, 813.

120. Dalla Torre, F.H.; Dubach, A.; Nelson, A.; Löffler, J.F. Temperature, strain and strain rate dependence of serrated flow in bulk metallic glasses. Mater. Trans. 2007, 48, 1774.

121. Dalla Torre, F.H.; Dubach, A.; Siegrist, M.; Löffler, J.F. Negative strain-rate sensitivity in bulk metallic glass and its similarities with the dynamic strain-aging effect during deformation. Appl. Phys. Lett. 2006, 89, 091918.

122. Trichy, G.R.; Scattergood, R.O.; Koch, C.C.; Murty, K.L. Influence of experimental parameters on the plastic flow curve obtained by ball indentation testing. Intermetallics 2005, 53, 1461. 
123. Hajlaoui, K.; Yavari, A.R.; Doisneau, B.; LeMoulec, A.; Botta, W.J.F.; Vaughan, G.; Greer, A.L.; Inoue, A.; Zhang, W.; Kvick, A. Shear delocalization and crack blunting of a metallic glass containing nanoparticles: In situ deformation in TEM analysis. Scr. Mater. 2006, 54, 1829-1834.

124. Guo, H.; Yan, P.F.; Wang, Y.B.; Tan, J.; Zhang, Z.F.; Sui, M.L.; Ma, E. Tensile ductility and necking of metallic glass. Nat. Mater. 2007, 6, 735.

125. Louzguine-Luzgin, D.V.; Yavari, A.R.; Xie, G.Q.; Madge, S.; Li, S.; Saida, J.; Greer, A.; Inoue, A. Tensile deformation behaviour of Zr-based glassy alloys. Philos. Mag. Lett. 2010, 90, 139.

126. Guo, H.; Yan, P.P.F; Wang, Y.B.; Tan, J.; Zhang, Z.F.; Sui, M.L.; Ma, E. Tensile ductility and necking of metallic glass. Nat. Mater. 2007, 6, 735-739.

127. Georgarakis, K.; Aljerf, M.; Li, Y.; Lemoulec, A.; Charlot, F.; Yavari, A.R.; Chornokhvostenko, K.; Tabachnikova, E.; Evangelakis, G.A.; Miracle, D.B.; Greer, A.L.; Zhang, T. Shear band melting and serrated flow in metallic glasses. Appl. Phys. Lett. 2008, 93, 031907.

128. Schuh, C.A.; Hufnagel, T.C.; Ramamurty, U. Mechanical behavior of amorphous alloys. Acta Mater. 2007, 5, 4067-4109.

129. Lewandowski, J.J.; Shazly, M.; Nouri, A.S. Intrinsic and extrinsic toughening of metallic glasses. Scr. Mater. 2008, 54, 337-341.

130. Caron, A.; Kawashima, A.; Fecht, H.J.; Louzguine-Luzguin, D.V.; Inoue, A. On the anelasticity and strain induced structural changes in a Zr-based bulk metallic glass. Appl. Phys. Lett. 2011, 99, 171907.

131. Louzguine-Luzgin, D.V.; Xie, G.; Zhang, Q.; Inoue, A. Cooling rate, structure, thermal stability and crystallization behaviour of Cu-based bulk glass-forming alloys. J. Phys. 2009, 144, 012047.

132. Cavaille, J.Y.; David, L.; Perez, J. Relaxation phenomena in non crystalline solids: Case of polymeric materials. Mater. Sci. Forum 2001, 366-368, 499-545.

133. Pelletier, J.M.; Louzguine-Luzgin, D.V.; Li, S.; Inoue, A. Elastic and viscoelastic properties of glassy, quasicrystalline and crystalline phases in $\mathrm{Zr}_{65} \mathrm{Cu}_{5} \mathrm{Ni}_{10} \mathrm{Al}_{7.5} \mathrm{Pd}_{12.5}$ alloys. Acta Mater. 2011, 59, 2797-2806.

134. Ke, H.B.; Wen, P.; Peng, H.L.; Wang, W.H.; Greer, A.L. Homogeneous deformation of metallic glass at room temperature reveals large dilatation. Scr. Mater. 2011, 64, 966-969.

135. Lee, S.C.; Lee, C.M.; Yang, J.W.; Lee, J.C. Microstructural evolution of an elastostatically compressed amorphous alloy and its influence on the mechanical properties. Scr. Mater. 2008, 58, 591.

136. Park, K.W.; Lee, C.M.; Wakeda, M.; Shibutani, Y.; Falk, M.L.; Lee, J.C. Elastostatically induced structural disordering in amorphous alloys. Acta Mater. 2008, 56, 5440.

(C) 2013 by the authors; licensee MDPI, Basel, Switzerland. This article is an open access article distributed under the terms and conditions of the Creative Commons Attribution license (http://creativecommons.org/licenses/by/3.0/). 